\title{
GEOLOGIA DO TONALITO ITARERU, BLOCO SERRINHA, BAHIA: UMA INTRUSÃO SIN-TECTÔNICA DO INÍCIO DA COLISÃO CONTINENTAL NO SEGMENTO NORTE DO ORÓGENO ITABUNA-SALVADOR-CURAÇÁ
}

\author{
MARCELO JULIANO DE CARVALHO \& ELSON PAIVA OLIVEIRA
}

\begin{abstract}
GEOLOGY OF THE ITARERU TONALITE, SERRINHA BLOCK, BAHIA: A SIN-TECTONIC INTRUSION FROM THE BEGINNING OF THE CONTINENTAL COLLISION IN THE ITABUNA-SALVADOR-CURAÇÁ OROGEN NORTHERN $S E G M E N T$ Elongated tonalitic bodies, associated with peridotite belts and large-scale shear zones, are important geological features for identifying sutures in orogenic belts. The Rio Itapicuru Greenstone Belt, located on the northeastern edge of the Palaeoproterozoic Itabuna-Salvador-Curaçá orogen, is made up mostly of metamorphosed mafic and felsic volcanics, and sediments, intruded by tonalite to granodiorite domes. Although a back-arc tectonic setting has been suggested, the location of the arc and of the suture zone, or even the relations with the basement have been hampered by deformation and paucity of high-quality isotope data. Recently, on the basis of Nd isotope data juvenile, arc-related tonalitic to granodioritic intrusions were recognized on the southern portion of the greenstone belt. New field studies also helped to recognize a NW-SE to N-S-trending tonalitic body that may mark the western boundary between the greenstone belt and the Archaean Retirolândia block within the Itabuna-Salvador-Curaçá Orogen. The Itareru Tonalite is a sheet-like body (up to $7.5 \mathrm{~km}$ wide and over $80 \mathrm{~km}$ long) composed of enclave-rich, porphyritic diorite to tonalite. Isotope studies indicated an age of $2,109 \pm 5 \mathrm{Ma}$ (U-Pb SHRIMP on zircons) and slightly negative $\mathrm{e}_{\mathrm{Nd}}$ values $(-0,79 \mathrm{a} 0,00)$. To the east of the Itareru Tonalite supracrustal rocks of the greenstone belt and foliated granitoids dominate, whereas Archaean banded gneisses, TTG and isotropic granitoids are the main rock-types to the west. It is suggested that the Itareru Tonalite defines a tectonic discontinuity between two terranes, and because of its syn-tectonic emplacement it possibly defines the timing of the Paleoproterozoic continentcontinent collision.
\end{abstract}

Keywords: Tonalite, terranes, geotectonics, geochronology

RESUMO Corpos tonalíticos alongados, assim como cinturões peridotíticos e zonas de cisalhamento de grande escala são características geológicas importantes na identificação de suturas em cinturões orogenéticos, quando expostos em suas partes profundas. O Greenstone Belt do Rio Itapicuru (GBRI), localizado na região nordeste do orógeno paleoproterozóico Itabuna-Salvador-Curaçá, é formado por rochas metavulcânicas máficas, félsicas e metassedimentares intrudidas por domos tonalíticos-granodioríticos. Apesar de um ambiente de back- arc ter sido sugerido para a formação do GBRI, a localização do arco e da zona de sutura, ou das relações embasamento/ cobertura têm sido dificultadas pela deformação, escassez de dados isotópicos de boa qualidade e pela falta de mapeamento detalhado de alguns corpos. Com base em dados de isótopos de $\mathrm{Nd}$ ( $\mathrm{T}_{\mathrm{DM}}$ muito próximas a idade de cristalização e eNd positivos), na porção sul do GBRI foram reconhecidas intrusões tonalíticas a granodioríticas com assinatura juvenil e afinidade geoquímica de arco insular. Trabalhos de campo possibilitaram a identificação de um corpo com orientação NW-SE a N-S que pode marcar o contato ocidental entre o GBRI e um bloco arqueano no Orógeno Itabuna-Salvador-Curaçá. Esse corpo, aqui denominado de Tonalito Itareru, tem forma de "folha", com aproximadamente $80 \mathrm{~km}$ de comprimento e até 7,5 km de largura, e é constituído por tonalito a diorito e granodiorito porfirítico, rico em enclaves. Dados isotópicos indicam uma idade de $2109 \pm 5 \mathrm{Ma}$ (SHRIMP U/Pb em zircão). Constatou-se que a leste do Tonalito Itareru predominam rochas supracrustais do GBRI e intrusões graníticas foliadas, enquanto, a oeste, predominam gnaisses bandados arqueanos, suites TTG e granitóides isotrópicos. Propõe-se que o Tonalito Itareru marque uma descontinuidade tectônica entre terrenos arqueanos e paleoproterozóicos, na região nordeste do Craton do São Francisco e, por sua natureza sintectônica, registra a época aproximada da colisão continental que deu origem ao Orógeno Itabuna-Salvador-Curaçá.

Palavras-chaves: Tonalito, terrenos metamórficos, geotectônica, geocronologia

INTRODUÇÃO Corpos tonalíticos sin-tectônicos tabulares têm sido descritos como importantes marcadores de limites entre terrenos tectono-metamórficos distintos em zonas transpressivas de colisão (Schimid et al. 1989, Ingram e Hutton 1994, Parry et al. 1997, Musumeci 1999). Esses corpos alojam-se ao longo de zonas de cisalhamento intra-crustais profundas e são gerados por subducção ou processos anatéticos, constituindo arcos magmáticos lineares paralelos às margens acrescionárias, com idades relacionadas à colisão.
Tal é a situação no sudeste do Alaska e na região de British Columbia, América do Norte, onde ocorre um complexo tonalítico sin-tectônico (Great Tonalite), de idade neocretácica, constituído por vários corpos tonalíticos cálcio-alcalinos tabulares. Esse complexo foi descrito como marcador de uma grande descontinuidade que separa os superterrenos Insular (terrenos Alexander e Wrangellia) e Supermontana (terrenos Stikine e Cache Creek) (Ingram \& Hutton 1994).

De modo semelhante, o cinturão tonalítico neocambriano de

Departamento de Geologia e Recursos Naturais, Instituto de Geociências, Unicamp, C.P. 6152, 13083-970, Campinas, SP. Email:carvalho@ige.unicamp.br 
North Victoria Land, Antártida, alonga-se paralelamente ao Orógeno de Ross, na paleomargem paleopaleozóica do Cráton Leste da Antártica. Este cinturão ocorre associado à zona de cisalhamento Lanterman-Murchison, marcando o limite entre os terrenos tectono-metamórficos Wilson e Bowers (Musumeci 1999).

Ocorrência semelhante às descritas acima foi identificada na margem ocidental do Greenstone Belt paleoproterozóico do Rio Itapicuru (GBRI), Bahia. Trata-se de um corpo sin-tectônico alongado, de composição tonalítico-diorítica a granodiorítica, denominado de Tonalito Itareru (TI) e, visando o entendimento de seu significado geodinâmico, este foi alvo de estudos detalhados, que envolveram mapeamento, geoquímica e geocronologia $\mathrm{U}-\mathrm{Pb}$, apresentados neste trabalho.

GEOLOGIA DOBLOCOSERRINHA OTonalito Itareru ocorre no Núcleo Arqueano de Serrinha (Mascarenhas 1979) ou Bloco Crustal de Serrinha (Barbosa 1986), situado na porção NE do Cráton do São Francisco, no estado da Bahia. Com um contorno em mapa aproximadamente retangular, o Bloco Serrinha é limitado à oeste pelo cinturão Paleoproterozóico Salvador-Curaçá (Padilha \& Melo 1991), ou segmento norte do Orógeno Itabuna-Salvador-Curaçá (este volume), sendo recoberto a leste pelos sedimentos fanerozóicos das bacias de Tucano e Recôncavo (Figs. 1 e 2).

O Bloco Serrinha é constituído por terrenos metamórficos arqueanos do Complexo Santa Luz, recobertos por unidades vulcano-sedimentares paleoproterozóicas do Greenstone Belt do Rio Itapicuru ou outras rochas (Brito Neves et al. 1980, Mascarenhas \& Garcia 1989, Silva 1992).

Complexo Santa Luz É caracterizado por gnaisses e migmatitos de idade arqueana com paragênese da fácies anfibolito (Mascarenhas \& Garcia 1989). Segundo Melo (1991), duas unidades litológicas distintas ocorrem: (i) gnaisses bandados, caracterizados pela alternância entre rochas gnáissicas cinzas (com biotita, hornblenda, microclina, plagioclásio e quartzo, como minerais principais) e bandas anfibolíticas com ou sem granada e (ii), ortognaisses granodioríticos a tonalíticos, com estruturas migmatíticas.

Zircões de gnaisses do Complexo Santa Luz foram recentemente datados pelo método U-Pb (SHRIMP), fornecendo idades entre 2983 Ma e 3152 Ma (Oliveira et al. 2002a,b, Mello et al. 1999), comparáveis às idades Rb-Sr obtidas por Mascarenhas \& Garcia (1989) e Pb-Pb apresentadas por Batista et al. (1998). Davison et al. (1988) citam discordância estrutural entre a foliação principal dos gnaisses do Complexo Santa luz e a foliação metamórfica das rochas do GBRI.

Greenstone Belt do Rio Itapicuru O Greenstone Belt do Rio Itapicuru (Kishida 1979, Kishida \& Riccio 1980) encontra-se inserido na porção leste do Bloco de Serrinha e forma uma faixa com orientação preferencial N-S, com $170 \mathrm{~km}$ de extenšão e $15 \mathrm{~km}$ de largura máxima. Ele é constituído por rochas máficas, félsicas e sedimentares de idade paleoproterozóica metamorfisadas em facies xisto verde a anfibolito, intrudidas por domos graníticos, com idades também paleoproterozóicas (Kishida 1979, Kishida \& Riccio 1980).

Silva (1983) agrupou as rochas do greenstone em três domínios principais: (i) o domínio vulcânico máfico que é representado por metabasaltos, brechas basálticas de fluxo e tufos máficos tendo sido obtida para os metabasaltos uma isócrona $\mathrm{Pb}-\mathrm{Pb}$ em rocha total de 2209 \pm 60 Ma Silva (1992); (ii) o domínio vulcânico félsico que se sobrepõe ao domínio vulcânico máfico sendo caracterizado por metandesitos, metadacitos e tufos andesito-dacíticos, valendo destacar que, nessa unidade Mascarenhas \& Garcia (1989) obtiveram idade isocrônica Rb-Sr de $2089 \pm 85 \mathrm{Ma}$, Silva (1992) uma isócrona $\mathrm{Pb}-\mathrm{Pb}$ em rocha total com idade de $2170 \pm 80 \mathrm{Ma}$, posteriormente, (Silva 1997), obteve idade de $2100 \mathrm{Ma}$ (iii) o domínio sedimentar que se sobrepõe aos outros dois e é constituído por metassiltitos, filitos, xistos aluminosos, metarenitos e metaconglomerados, não havendo datações neste pacote sedimentar.

Do ponto de vista estrutural, o GBRI apresenta orientação preferencial N-S nas porções setentrional e central, e E-W na porção meridional, possuindo uma sucessão de antiformes e sinformes com eixos orientados segundo tais direções. Zonas de cisalhamento paralelas ao acamamento $\left(\mathrm{S}_{0}\right)$ e à foliação regional $\left(S_{1}\right)$ são comuns nas três porções. Segundo Alves da Silva (1994), a deformação no GBRI é resultado de dois principais eventos estruturais $\left(\mathrm{D}_{1}\right.$ e $\left.\mathrm{D}_{2}\right)$, ambos sob condições da fácies xisto-verde/ anfibolito. O evento $D_{1}$ está preservado na porção sul do GBRI e é caracterizado por foliação de baixo ângulo mergulhante para SE, associada a cavalgamentos com vergência para NW. A esse evento associa-se a colocação de granitódes sin-tectônicos como o de Barrocas (Alves da Silva 1994). O evento $D_{2}$ é mais intensamente marcado na região e, conforme Alves da Silva (1994), pode ser dividido em duas fases: $F_{1}$ de fechamento da bacia vulcanossedimentar, quando desenvolveram-se empurrões para SE e, $\mathrm{F}_{2}$ de natureza transcorrente, caracterizado por cisalhamento dúctil sinistral ao longo de zonas NS subverticais. À última fase estão relacionadas intrusões graníticas paleoproterozóicas como a do Domo do Ambrósio (Alves da Silva 1994).

Rochas Intrusivas no Bloco Serrinha As rochas intrusivas são representadas por vários granitóides de diferentes composições. Ocorrem intrudidos na seqüência vulcano-sedimentar ou margeando-a. São corpos ovalados ou elipsoidais que podem ser divididos em dois principais tipos: corpos isotrópicos e domos granito-gnáissicos. Essas rochas têm sido alvo de trabalhos específicos de mapeamento e caracterização litogeoquímica (Matos 1988, Matos \& Conceição 1993, Rios et al. 1998, Barrueto et al. 1998, Lacerda 2000). Apesar disso, dados isotópicos ainda são relativamente escassos nessas rochas.

Rios et al. (1998) classificaram as rochas graníticas da parte suloriental do Bloco Serrinha em cinco principais grupos.

O grupo Gl é representado por doze intrusões, como as de Teofilândia, Barrocas, Itareru e Santa Luz, sendo essa última a que tipifica o grupo. O corpo de Santa Luz é representado por rochas leucocráticas de granulação média a grossa, com composição variando desde biotita-granodiorito até monzogranito, bastante deformado, gnaissificado, localmente com aspecto migmatítico (Rios et al. 1998). Rios et al. (1998) obtiveram idades $\mathrm{Pb}-\mathrm{Pb}$ (evaporação de Pb em zircão) para o corpo de Santa Luz de 2468 \pm 3 Mae $2076 \pm 19$ $\mathrm{Ma}$, enquanto Chauvet et al. (1997) encontraram idade de $2127 \mathrm{Ma}$ para a intrusão de Barrocas (evaporação de $\mathrm{Pb}$ em zircão).

O grupo G2 é representado pelos maciços de Ambrósio, Pedra Alta, Poço Grande e Salgadália, sendo o primeiro o corpo típico. São corpos localizados nas zonas centrais de antiformes que afetam o GBRI, têm forma elíptica e estão alongados segundo a direção N-S. O corpo de Ambrósio apresenta composição granodiorítica com bordas fortemente gnaissificadas, e as porções centrais mais isotrópicas de composição granítica (Lacerda 2000). Mello et al. (1999) obtiveram idade de $2080 \pm 2 \mathrm{Ma}$ (U-Pb SHRIMPem xenotímio) 


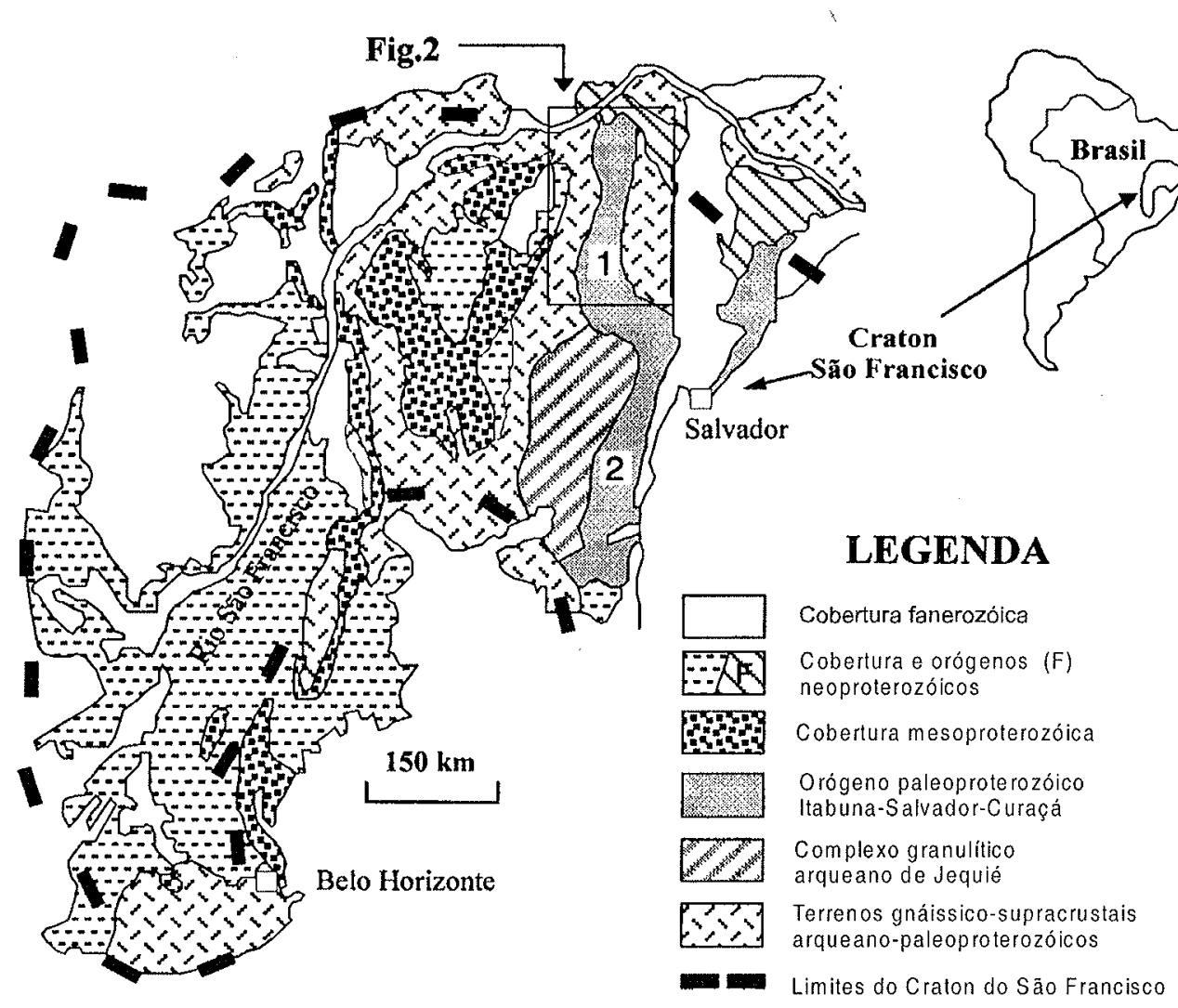

Figura 1 - O Craton São Francisco com a localização dos segmentos norte (1) e sul (2) do orógeno Itabuna-Salvador-Curaçá (adaptado de Oliveira \& Tarney 1995).

para granito do Domo de Ambrósio.

Os granitóides G3 caracterizam-se por formas ovóides e incluem os maciços de Nordestina, Lagoa dos Bois e Eficéas. O Maciço de Nordestina apresenta grande quantidade de xenólitos de anfibolito, a oeste, e de rochas metavulcânicas máficas, a leste (Inda \& Barbosa 1978). Duas facies principais são descritas: uma representada por hornblenda granodiorito e outra por hornblenda granodiorito porfirítico. Alves da Silva (1994) obteve idades por evaporação de $\mathrm{Pb}$ que variaram de $2100 \pm 10 \mathrm{Ma}$ a $2004 \pm 103 \mathrm{Ma}$ para o maciço de Nordestina. O maciço de Lagoa dos Bois aparece em classificações anteriores às de Rios et al. (1998), como pertencente ao grupo Gl (Matos \& Conceição 1993), entretanto, segundo os primeiros autores as características petrográficas e geoquímicas permitem incluí-lo no grupo G3.

O grupo G4 possui termos com afinidade shoshonítica e outros com afinidade alcalino-potássica. O maciço de Cansanção corresponde ao corpo típico desse grupo. É constitulído por rochas de composição monzonítica a monzodiorítica, shoshonítica, e está intrudido no Maciço de Nordestina. Datações $\mathrm{Pb}-\mathrm{Pb}$ por evaporação em grãos de zircão indicam idade de $2105 \pm 3$ Ma para essas rochas (Rios et al. 1998).

Os granitóides G5 ocorrem como stocks praticamente isotrópicos e têm como corpo típico o de Morro do Lopes. Este corpo é um biotita monzogranito leucocrático, de coloração cinza, granulação fina e estrutura isotrópica. Normalmente, os granitos deste grupo apresentam estruturas de fluxo magmático não deformadas, revelando que são posteriores às principais deformações regionais.
Além de stocks, esses corpos também ocorrem em forma de diques que cortam as rochas do embasamento e os granitóides mais antigos. Rios et al. (2000) encontraram idade U-Pb de $2072 \pm 1 \mathrm{Ma}$ em zircões do Granito Morro do Lopes.

Evolução Regional O Cinturão Móvel Salvador-Curaçá, que constitui parte do segmento norte do Orógeno Itabuna-SalvadorCuraçá, é composto por rochas metamorfisadas em facies granulito. Segundo Figueiredo (1989) e Teixeira \& Figueiredo (1991) esse Cinturão foi gerado pela colisão entre o microcontinente Jequié e o maciço do Gabão (África), com uma zona de subducção mergulhando para oeste, associada a um arco magmático de margem continental na porção sudeste do Orógeno.

Padilha \& Melo (1991) propuseram vários estágios para a evolução regional. Segundo esses autores, há $2750 \pm 50 \mathrm{Ma}$ a crosta arqueana foi desmembrada por um rifte no qual gerou-se uma crosta oceânica individualizando-se assim os blocos Serrinha e Mairi. Haveria, então, subducção intraoceânica para leste e geração de arco magmático. O Complexo Caraíba, constituído dominantemente por rochas granulíticas de composição granodiorítica, representaria a raiz desse arco. Há cerca de $2300 \pm 50$ Ma teria lugar uma colisão continental, formando o Cinturão Móvel SalvadorCuraçá. O GBRI teria se formado a partir do rifteamento do Bloco Serrinha, há cerca de $2060 \pm 50 \mathrm{Ma}$, e a Bacia de Jacobina pelo rifteamento do Bloco Mairi.

Padilha (1992) sintetizou as informações sobre a evolução geotectônica do Cinturão Salvador-Curaçá, propondo que o mes- 


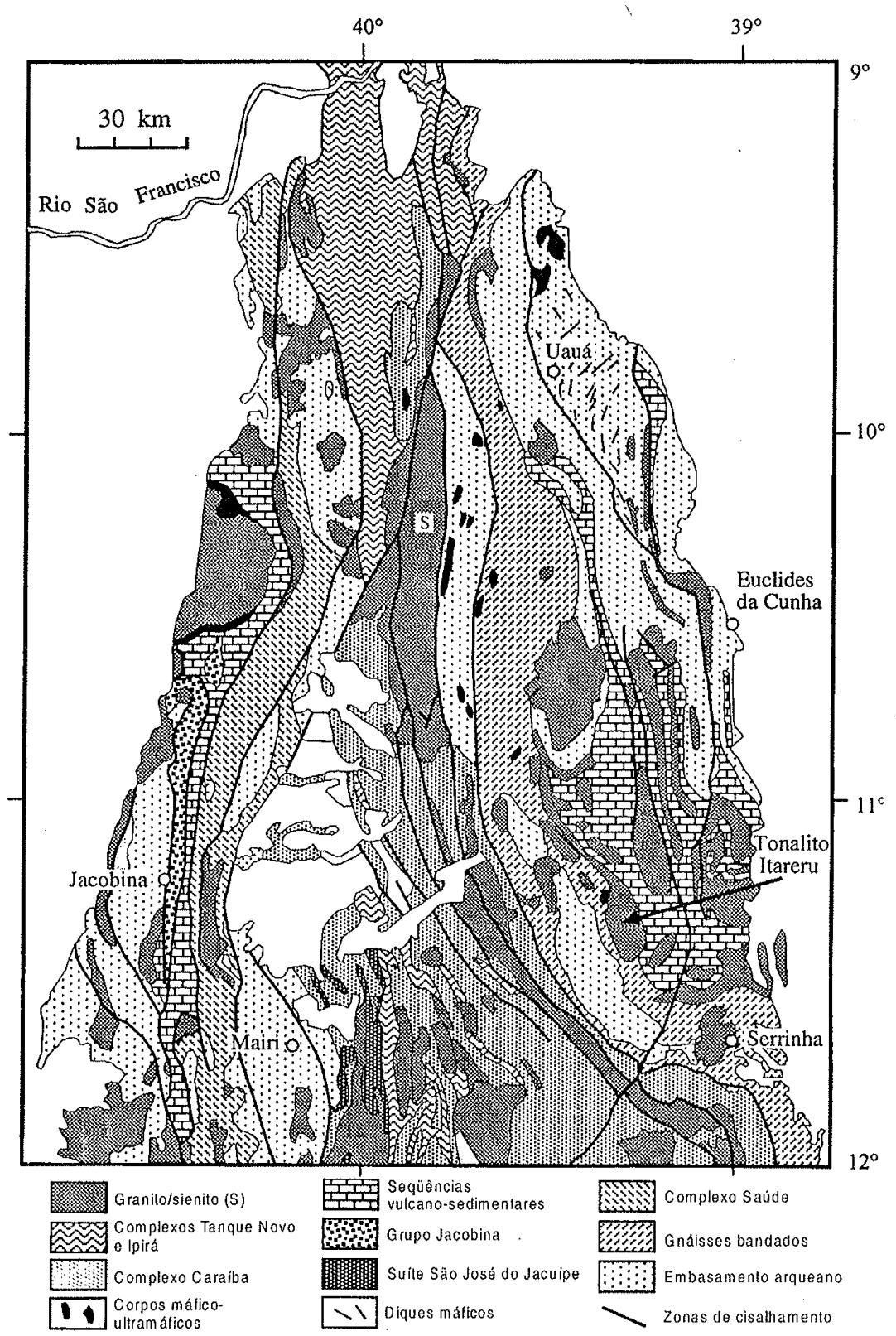

Figura 2 - Mapa geológico do segmento norte do Orógeno Itabuna-Salvador-Curaçá (modificado de Kosin et al. 1999), com a localização do Tonalito Itareru.

mo representaria a zona axial de uma estrutura em flor positiva, gerada através de dois principais eventos deformacionais transpressivos. As rochas granulíticas do cinturão estariam cavalgadas, a leste, sobre as rochas supracrustais do GBRI.

Silva (1992) e Matos \& Conceição (1993) propuseram, como estágio inicial da evolução da área, a abertura de um oceano no Paleoproterozóico, o qual corresponderia à bacia de Jacobina. A crosta oceânica gerada teria sido consumida, a leste, simultaneamente à formação de uma bacia de retroarco onde teria se depositado as rochas do GBRI. Os sedimentos da frente do arco seriam representados pelas rochas metassedimentares do Complexo Caraíba.

Silva (1992) descreveu o ambiente tectônico de formação do
GBRI como similar aos de bacias retroarco modernas, com extrusão de vulcânicas félsicas no arco de ilhas formado pela convergência entre as duas placas envolvidas. A subducção provocaria extensão da borda continental passiva, resultando em rifteamento e abertura de uma bacia e conseqüente extrusão de basaltos oceânicos (domínio vulcânico máfico). O domínio sedimentar seria representado por sedimentos erodidos do arco de ilhas. Todo esse conjunto teria sido, então, intrudido por granitóides, representados por domos granodiorítico-tonalíticos.

Alves da Silva (1994) sugeriu um modelo diferente dos anteriores para o GBRI, que eram norteados por subducção para oeste ou para leste. Segundo este autor, há aproximadamente 2200 Ma teve início a abertura de um rifte intracontinental que gerou uma bacia 
onde foram depositadas as rochas vulcanossedimentares do GBRI. Há cerca de $2127 \mathrm{Ma}$ iniciou-se o fechamento da bacia durante o evento tectônico $D_{1}$, compressivo, com vergência para NW, gerando a foliação regional da parte sul do GBRI. Associado a esse evento houve alojamento dos corpos tonalítico-granodioríticos de Barrocas e Teofilândia. Em seguida, continuou o fechamento da bacia vulcano-sedimentar, gerando empurrões e dobras com vergência para SE. Finalmente, há $2100 \mathrm{Ma}$ houve a intrusão dos corpos granodioríticos do tipo Ambrósio e, com isso, mudança no estilo da deformação, formando zonas de cisalhamento direcionais N-S. Os principais argumentos usados por Alves da Silva (1994) são a indefinição sobre a localização do arco magmático, gerado pelas subducções propostas (para oeste ou leste) nos outros modelos, e a incerteza sobre a existência de crosta oceânica envolvida nos processos evolutivos.

\section{OTONALITOITARERU, ENCAIXANTESE ROCHAS ASSO-}

CIADAS OTonalito Itareru (TI) foi citado pela primeira vez por Rios et al. (1998), que o enquadraram, juntamente com outros corpos, como representativo das primeiras intrusões graníticas no GBRI (grupo G1). Entretanto, com o mapeamento desenvolvido para este trabalho, e à luz de novos dados geoquímicos e isotópicos, constatou-se a necessidade de redefinir esta unidade granitóide.

O Tonalito Itareru é um corpo alongado com forma de "folha", localizado na borda ocidental do GBRI, estendendo-se de forma contínua por cerca de $80 \mathrm{~km}$, desde a região a sul do povoado de Itareru até o extremo SE do corpo granítico de Nordestina (Fig. 3). É caracterizado por duas intrusôes, separadas por uma estreita faixa de anfibolitos e gnaisses, e é constituído por rochas de composição tonalito-granodiorítica a diorítica, porfiríticas, portadoras de enclaves máficos, centimétricos a decimétricos, de composição anfibolítica a diorítica. Está orientado segundo a direção NW-SE a $\mathrm{N}-\mathrm{S}$ e mergulha em ângulos variados, quase sempre para E. Sua espessura varia de $7,5 \mathrm{~km}$, nas proximidades de Itareru, até $100 \mathrm{~m}$, a norte da cidade de Santa Luz. Sua terminação sul pode ser observada a sudoeste de Itareru, na Fazenda Angico, e se dá através de uma rampa de empurrão com topo deslocado para SSE. O fechamento norte se dá junto à borda SE do pluton de Nordestina.

O Tonalito Itareru é caracterizado pela presença constante de lineação mineral e a quase ausência de foliação ígnea ou metamórfica, correspondendo deste modo a um tectonito tipo L. Foliação ocorre apenas no contato com os gnaisses regionais, com as rochas do GBRI, e com o Granodiorito Lagoa do Boi, que o intrude. É cortado por diques félsicos a máficos, veios aplíticos e pegmatíticos, e pelo corpo granodiorítico de Lagoa do Boi.

Os diques félsicos, presentes em toda a sua extensão, variam de espessura, porém nunca ultrapassam $1 \mathrm{~m}$. Apresentam-se sempre paralelos à lineação mineral e, localmente, mostram-se dobrados. Esses diques assemelham-se mineralogicamente aos granitóides de Morro do Lopes (G5).

Os veios aplíticos que o cortam são de duas gerações. A primeira é truncada pelas rochas granodioríticas do tipo Lagoa do Boi, e a segunda corta essas rochas. Veios pegmatíticos são as intrusões mais novas, que atravessam as demais rochas.

Um único xenólito foi observado em sua porção norte. Trata-se de rocha máfica fina, provavelmente um metabasalto, com aproximadamente $3 \mathrm{~m}$ de comprimento por 1,5 $\mathrm{m}$ de largura.

O mapeamento geológico permitiu a identificação de três principais litofácies: (i) fácies tonalítica, que predomina e ocorre em toda a faixa central e oriental do corpo; (ii) fácies granodiorítica, que ocorre restrita à porção norte do corpo e, (iii) fácies diorítica que predomina apenas na faixa SW do corpo, na intrusão separada pela faixa de gnaisses e anfibolitos da sequência bandada (Fig. 3).

Dois tipos de granitóides foram reconhecidos a leste e a oeste do TI. Enquanto a leste afloram os domos graníticos gnáissicos do tipo Ambrósio (G2), sempre deformados e provavelmente gerados por fusão parcial de rochas do embasamento (Lacerda, 2000), a oeste ocorrem pequenas serras e elevações compostas por granitóides de granulação fina a média e praticamente isotrópicos, do tipo Morro do Lopes.

Petrografia e Geoquímica O Tonalito Itareru é composto por quartzo, plagioclásio, hornblenda e biotita, como minerais principais. Titanita e alanita ocorrem como acessórios mais comuns, sendo o primeiro bastante abundante. A textura é granular, com

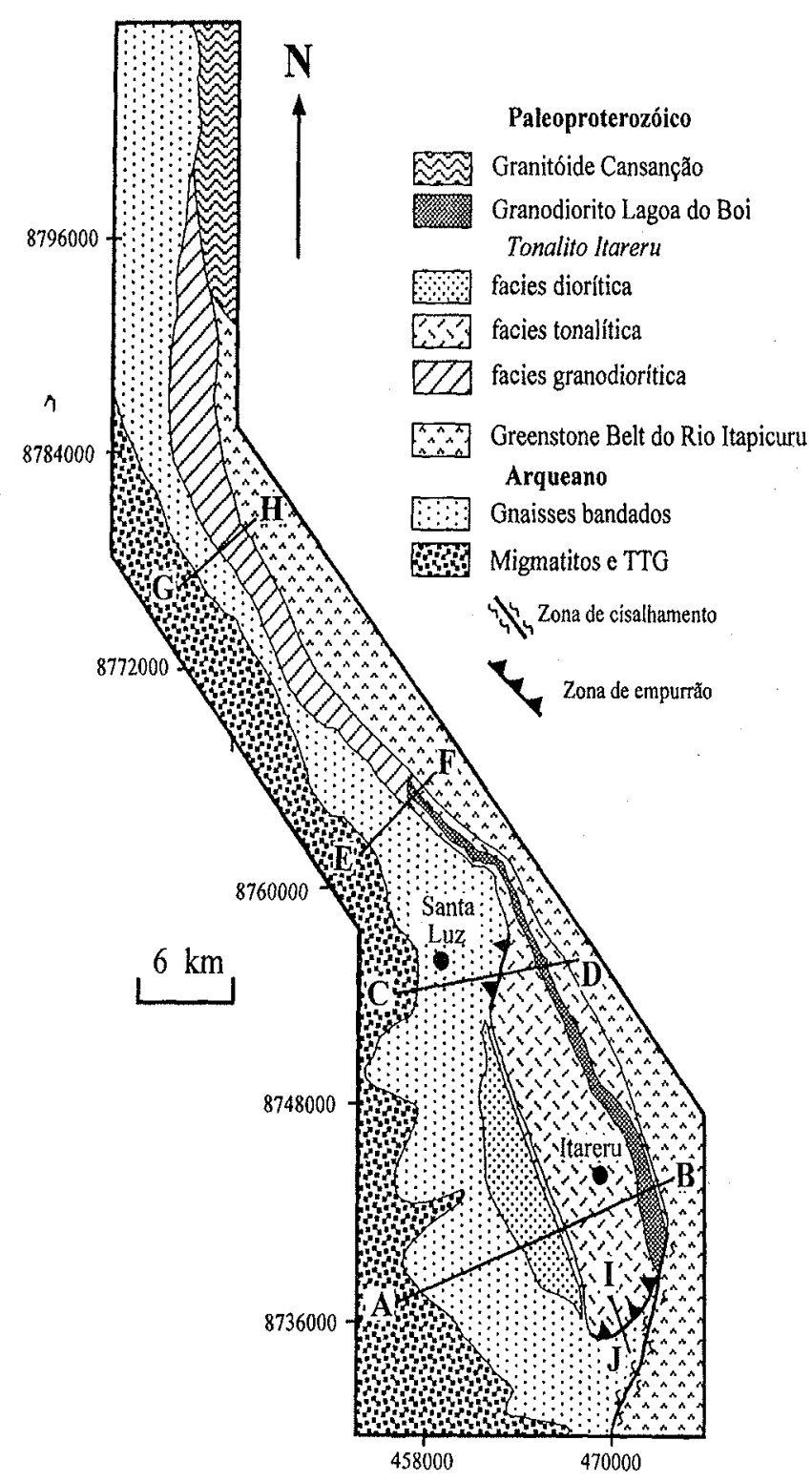

Figura 3 - Mapa geológico da região de exposição do Tonalito Itareru, com indicação dos perfis ilustrados na figura 5 (adaptado de Carvalho 2001). 
plagioclásio euédrico a subédrico e arranjo em mosaico entre quartzo e feldspato. A hornblenda também é bem formada e quase nunca apresenta recristalizações, a não ser nas zonas de maior deformação. A biotita ocorre junto à hornblenda, com contatos abruptos entre ambas. Na borda do corpo, a textura é granoblástica, com recristalização de quartzo e plagioclásio, porém, sem recristalização de anfibólio.

As rochas do TI podem ser agrupadas em três fácies: tonalítica, granodiorítica e diorítica.

A facies tonalítica predominante ocupa toda a porção centro sul do corpo e está representada por biotita-hornblenda tonalitos porfiríticos, constituídos em média por $39 \%$ de quartzo, $35,9 \%$ de plagioclásio, $18,3 \%$ de hornblenda, $6,0 \%$ de biotita, $0,5 \%$ de minerais acessórios e $0,3 \%$ de microclina. A granulação é média a grossa. Os fenocristais, de até $3 \mathrm{~cm}$, são todos de plagioclásio e perfazem um total de $13,9 \%$ da rocha. Os minerais acessórios mais comuns são titanita e alanita. Nas porções centrais, o tonalito apresenta textura ígnea, com plagioclásio euédrico. A biotita é primária e, junto com o anfibólio subeuédrico, contorna os fenocristais de plagioclásio. Nas porções deformadas, mais próximas à borda do corpo, o quartzo é bastante estirado, com extinção ondulante e migração de limites de subgrãos. O plagioclásio também apresenta extinção ondulante e, nos domínios onde a deformação é mais intensa, apresenta bordas recristalizadas e sombras de pressão de quartzo recristalizado.

A fácies granodiorítica ocorre na porção norte do corpo. Em média é composta por $37,9 \%$ de plagioclásio, $19,7 \%$ de quartzo, $17,2 \%$ de feldspato potássico (microclina), $14,6 \%$ de hornblenda, $10,3 \%$ de biotita e $0,3 \%$ de acessórios. Titanita e, subordinadamente, alanita são os principais acessórios. Compreende rochas porfiríticas de granulação média, com matriz frequientemente recristalizada, com fenocristais de plagioclásio, microclina e anfibólio, perfazendo um total de $21,2 \%$ da rocha (13,2\% de plagioclásio, $4,1 \%$ de microclina e $3,9 \%$ de hornblenda). Os fenocristais de feldspato podem atingir até $3 \mathrm{~cm}$. A hornblenda é sub-euédrica e, normalmente, apresenta bordas corroídas. $\mathrm{O}$ plagioclásio tem fraco zoneamento. Em porções deformadas, próximas à borda do corpo, os fenocristais de plagioclásio apresentam sombras de pressão de microclina e/ou quartzo. A microclina também preenche os interstícios de plagioclásio, quartzo e anfibólio, demonstrando ser também uma fase tardia. O quartzo é estirado com extinção ondulante.

A fácies diorítica está restrita à porção centro-oeste do corpo, sendo separada da fácies tonalítica por uma faixa de anfibolitos e gnaisses bandados. As rochas dessa fácies são afíricas e compostas em média por $48,7 \%$ de plagioclásio, $31,9 \%$ de hornblenda, $9 \%$ de quartzo, $6,9 \%$ de microclina, $2,4 \%$ de biotita e $0,4 \%$ de hiperstênio. Titanita e alanita ocorrem como principais acessórios. Em relação às outras fácies, esta é mais deformada, tem granulação mais fina e maior quantidade de anfibćlio. A hornblenda ocorre em grãos subeuédricos com textura poiquilítica. Piroxênio ocorre subordinadamente.

As microestruturas relacionadas ao estado de cristalização são de dois tipos principais: PFC (Pre-Full Crystallization Fabric), característica de foliação magmática, e CPS (Crystal Plastic Strain Fabric), característica da deformação em estado sólido. Esses tipos de trama variam do centro para as bordas do corpo. Na região central, dominam tramas do tipo PFC, com pouca ou nenhuma deformação, enquanto nas bordas são do tipo CPS, com o incremento da deformação.

Análises químicas de elementos maiores, traços e de terras raras foram realizadas, para melhor entender a petrogênese das rochas do TDI e suas implicações na reconstrução geotectônica regional.

As análises de elementos maiores e traços foram obtidas por espectrometria de fluorescência de Raios X e os elementos terras raras por ativação neutrônica. Os resultados para amostras representativas de tonalitos, dioritos e granodioritos são apresentados na Tabela 1 .

O TI apresenta valores de $\mathrm{SiO}_{2}$ entre 51,60\% e 67,29\%. O índice de saturação em alumínio é típico de rochas metaluminosas (Fig. $4 \mathrm{a}$ ), enquanto os valores de $\mathrm{K}_{2} \mathrm{O} v s$. $\mathrm{SiO}_{2}$ mostram que as rochas do TI pertencem à série cálcio-alcalina de alto potássio (Fig. 4b).

No diagrama de índice de Peacock, modificado por Brown (1982) (Fig. 4c), as rochas do TI pertencem à série alcali-cálcica, porém com alguma dispersão dos dados em valores mais elevados de $\mathrm{SiO}_{2}$. No diagrama AFM (Fig. 4d), as rochas do TI definem uma clara tendência cálcio-alcalina, com porcentagem relativamente baixa em FeO.

No diagrama de discriminação de ambiente tectônico $\mathrm{Rb} v s . \mathrm{Y}+\mathrm{Nb}$ (Pearce et al. 1984) as amostras situam-se no campo das rochas de $\operatorname{arcos}$ magmáticos (Fig. 4e).

Nos diagramas multi-elementares normalizados ao manto primitivo, as amostras do TI apresentam anomalias negativas de $\mathrm{Nb}$ e $\mathrm{Ti}$, e praticamente nenhuma de $\mathrm{Sr}$ (Fig. 4f). A anomalia negativa de $\mathrm{Nb}$ é geralmente considerada uma característica de magmas gerados em zonas de subducção (e.g. Condie 1997).

Para fins de comparação, na figura $4 \mathrm{f}$ também foram plotadas análises de tonalitos Neocretácicos relacionados à zona de subducção de Taiwan (Lan et al. 1996) e de tonalitos neoproterozóicos de arco magmático da Etiópia (Wold et al. 1996). Nota-se semelhança entre as amostras do TI e aquelas acima referidas, revelando afinidade geoquímica das rochas do TI com magmatismo de zonas de subducção.

Relações de Contato do Tonalito Itareru com as Rochas Encaixantes e Intrusivas O TI está colocado entre as rochas supracrustais paleoproterozóicas do GBRI, a leste, e as rochas arqueanas do Complexo Santa Luz, a oeste (Figs. 3 e 5).

A sul, o TI está em contato com gnaisses e anfibolitos, da unidade de gnaisses bandados. O contato é claramente tectônico e caracteriza uma rampa de cavalgamento de aproximadamente $6 \mathrm{~km}$ de extensão lateral. Esse cavalgamento, com topo para S-SE, colocou as rochas do TI sobre os gnaisses bandados do Complexo Santa Luz (Fig. 5e). Nesse local, as rochas do TI apresentam foliação E-W, muito penetrativa, com lineações de estiramento down dip, mergulhando em baixo ângulo para norte.

A oeste, o TI também está em contato com gnaisses bandados do Complexo Santa Luz, tendo a zona de contato diferentes características, de sul para norte (Fig. 5).

$\mathrm{Na}$ região $\mathrm{SW}$, o contato é caracterizado por mergulhos suaves $\left(20^{\circ} / 30^{\circ}\right)$ para $\mathrm{E}$ e os gnaisses bandados exibem dobras fechadas (Fig. 5a). Um pouco mais a norte (Fig. 5b), os gnaisses bandados foram empurrados sobre o TI. Já na região setentrional, onde o TI é mais estreito, o contato com os gnaisses bandados caracterizase por mergulhos bem mais fortes, até verticais, por vezes em alto ângulo para W (Fig. 5 c,d).

A leste, o TI está em contato com anfibolitos (metabasaltos), representantes das rochas supracrustais do GBRI. O contato caracteriza-se por mergulhos em médio/alto ângulos $\left(50^{\circ}-70^{\circ}\right)$ quase sempre para E. Como é observado na borda ocidental, aqui também há um aumento do ângulo de mergulho das rochas para norte, chegando, em alguns pontos, a mergulhos verticais ou até em alto 
Tabela 1 - Análises químicas representativas de rochas do Tonalito Itarenu, ordenadas segundo valores crescentes de SiO

\begin{tabular}{|c|c|c|c|c|c|c|c|c|c|c|c|}
\hline A mostra & $78-2$ & $130 \mathrm{~B}$ & $136 \mathrm{~B}$ & $97 \mathrm{~B}$ & 173 & $129 \mathrm{~A}$ & $130 \mathrm{~A}$ & $79 \mathrm{~A}$ & 58 & $61 \mathrm{~B}$ & 126 \\
\hline $\mathrm{SiO}_{2}$ & 51.6 & 54,66 & 54.9 & 55,8 & 57,05 & 57,86 & 58.79 & 59,7 & 60,03 & 60,52 & 65.74 \\
\hline $\mathrm{TiO}_{2}$ & 1,09 & 1,5 & 0,86 & 0,91 & 0.86 & 0.75 & 0.83 & 0.79 & 0,76 & 0.78 & 0.54 \\
\hline $\mathrm{Al}_{2} \mathrm{O}_{3}$ & 16,67 & 12,84 & 16,24 & 16,29 & 16,96 & 15,8 & 15,04 & 16,11 & 15,35 & 15,72 & 14,6 \\
\hline $\mathrm{Fe}_{2} \mathrm{O}_{3}$ & 8,52 & 7,26 & 6,95 & 7,15 & 6,81 & 6,38 & 6,17 & 6,32 & 6,16 & 6.12 & 4,25 \\
\hline $\mathrm{MnO}$ & 0,13 & 0,12 & 0,14 & 0,1 & 0,1 & 0,11 & 0,09 & 0,09 & 0,09 & 0,09 & 0,07 \\
\hline $\mathrm{MgO}$ & 5,53 & 5,28 & 3,86 & 4,56 & 3,93 & 2.72 & 4,08 & 3,72 & 3,99 & 3.63 & 2.37 \\
\hline $\mathrm{CaO}$ & 7,9 & 7,29 & 7,02 & 6,91 & 6,41 & 6,18 & 5,77 & 5,8 & 5,55 & 5,52 & 3,71 \\
\hline $\mathrm{Na}_{2} \mathrm{O}$ & 4,26 & 1,87 & 4,36 & 4,31 & 4,53 & 3,78 & 4,14 & 4,2 & 3,64 & 4.02 & 4.17 \\
\hline $\mathrm{K}_{2} \mathrm{O}$ & 2,34 & 6,2 & 3,48 & 2,63 & 2,26 & 4.87 & 3,67 & 2,72 & 3,25 & 2,85 & 3,77 \\
\hline $\mathrm{P}_{2} \mathrm{O}_{5}$ & 0,78 & 1,21 & 0,67 & 0,67 & 0,55 & 0,56 & 0.62 & 0.49 & 0,49 & 0.49 & 0,36 \\
\hline LOI & 0,68 & 0,65 & 0,58 & 0,71 & 0,38 & 0,42 & 0,6 & 0,34 & 0,32 & 0,38 & 0,89 \\
\hline Total & 99,5 & 98,88 & 99,06 & 100,04 & 99,84 & 99,43 & 99,8 & 100,28 & 99.63 & 100,12 & 100,47 \\
\hline $\mathrm{V}$ & 147 & 155 & 127 & 125 & 112 & 123 & 104 & 101 & 106 & 100 & 63 \\
\hline $\mathrm{Cr}$ & 162 & 130 & 99 & 134 & 102 & 50 & 146 & 103 & 129 & 118 & 76 \\
\hline $\mathrm{Ni}$ & 63 & 110 & 47 & 56 & 42 & 34 & 56 & 41 & 50 & 39 & 29 \\
\hline $\mathrm{Cu}$ & 11 & 5 & 36 & 35 & 25 & 21 & 26 & 22 & 21 & 22 & 6 \\
\hline $\mathrm{Zn}$ & 126 & 126 & 120 & 107 & 102 & 105 & 88 & 94 & 89 & 89 & 74 \\
\hline $\mathrm{Rb}$ & 55 & 159 & 104 & 65 & 57 & 120 & 99 & 73 & 89 & 75 & 131 \\
\hline$S r$ & 1276 & 2081 & 2495 & 1443 & 1221 & 2775 & 1632 & 1072 & 1064 & 1028 & 944 \\
\hline Y & 37 & 60 & 44 & 32 & 28 & 63 & 34 & 25 & 28 & 27 & 23 \\
\hline $\mathrm{Zr}$ & 293 & 933 & 347 & 312 & 252 & 581 & 332 & 229 & 245 & 226 & 208 \\
\hline $\mathrm{Nb}$ & 7 & 15 & 5 & 8 & 6 & 14 & 11 & 6 & 7 & 7 & 8 \\
\hline $\mathrm{Ba}$ & 1388 & 4026 & 3462 & 1896 & 1540 & 4385 & 1993 & 1575 & 1695 & 1532 & 1434 \\
\hline $\mathrm{Pb}$ & 16 & 36 & 38 & 24 & 17 & 42 & 32 & 23 & 23 & 22 & 41 \\
\hline Th & 6 & 23 & 19 & 17 & 13 & 32 & 15 & 12 & 15 & 14 & 24 \\
\hline La & 92 & & 196 & & & & & & 88 & & 93 \\
\hline $\mathrm{Ce}$ & 195 & & 357 & & & & & & 174 & & 183 \\
\hline $\mathrm{Nd}$ & 92 & & 169 & & & & & & 83 & & 74 \\
\hline$S m$ & 17,6 & & 26 & & & & & & 13.5 & & 12,7 \\
\hline Eu & 4,9 & & 7,3 & & & & 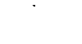 & & 3,6 & & 3,1 \\
\hline $\mathrm{Tb}$ & 1,8 & & 2 & & & & & & 1,3 & & 0,94 \\
\hline $\mathrm{Yb}$ & 3,3 & & 1,9 & & & & & & 2 & & 1,84 \\
\hline Lu & 0,33 & & 0,25 & & & & & & 0,28 & & 0,25 \\
\hline
\end{tabular}

ângulo para $W$.

O limite norte do TI é próximo ao Granitóide de Nordestina. Uma característica que distingue os contatos oriental e ocidental do TI é a natureza das rochas que o cortam. A leste, o TI é seccionado por rochas gnáissico-miloníticas da unidade Granodiorito Lagoa dos Bois, enquanto a oeste é cortado por rochas graníticas, praticamente isotrópicas e com orientação aleatória, pertencentes aos granitóides tipo Morro do Lopes, ou do grupo G5 na classificação de Rios et al. (1998).

Rochas Encaixantes e Intrusivas GRANODIORITO LAGOADO $B O I$ OTI é seccionado pelo corpo granodiorítico Lagoa do Boi, com foliação magmática e alongado na direção N-NW. Este corpo estende-se por aproximadamente $30 \mathrm{~km}$, desde o povoado de Itareru até alguns quilômetros a norte de Santa Luz (Fig. 3). Tem sua maior largura (aproximadamente 1,5 km) e expressão topográfica na $\mathrm{Fa}$ zenda Lagoa do Boi, da qual levou o nome. Matos \& Conceição (1993) o classificaram como granitóide do grupo Gl. Rios et al. (1998) com base em dados petrográficos e geoquímicos o reclassificaram como granitóide do grupo $\mathrm{G} 3$.

O Granodiorito Lagoa do Boi ocorre na região mais oriental do $\mathrm{TI}$, ou em contato intrusivo direto com as rochas supracrustais do GBRI. Apresenta-se em antiforme alongado com foliação em alto ângulo e mergulhos sempre para fora do corpo. A leste, a foliação mergulha $70^{\circ}-80^{\circ}$ para $E$, enquanto que, a oeste, mergulha para $W$, ajustando-se ao contato com o TI. O granodiorito está sempre cortado por diques félsicos dobrados, com feições migmatíticas, e subordinadamente por diques máficos. Nota-se, sempre, a pre- sença de anfibolitos, provavelmente do GBRI, nos contatos leste e oeste com o TI. O granodiorito Lagoa do Boi ocorre ainda como diques satélites, centimétricos a métricos, cortando o TI. Esses diques normalmente contêm xenólitos do TI.

Suas rochas apresentam-se sempre deformadas e são constituídas por quartzo, plagioclásio, biotita, hornblenda e microclina. $\mathrm{O}$ quartzo exibe extinção ondulante e está bastante estirado, formando "fitas" que marcam bem a lineação de estiramento. A biotita orienta-se paralelamente às "fitas" de quartzo. O plagioclásio é euédrico a subeuédrico, mas está quase sempre deformado e recristalizado. Mirmequita ocorre em todas as amostras.

GNAISSES BANDADOS A oeste do TI ocorre uma seqüência de gnaisses bandados, caracterizados por intercalações de quartzobiotita-gnaisses cinza e anfibolitos, estes com ou sem granada, metamorfisados em fácies anfibolito. Essa unidade estende-se por, pelo menos, $70 \mathrm{~km}$ para norte e orienta-se também segundo a principal direção regional N-NW. O seu contato com o TI não é observado em campo, pela escassez de exposições.

Os gnaisses bandados representam uma das duas unidades que compõem o Complexo Santa Luz, conforme descrito por Melo (1991). Suas estruturas características são foliação penetrativa e intenso dobramento. $\mathrm{O}$ bandamento da unidade varia de centimétrico a métrico. Relações de truncamento entre anfibolito e gnaisse e a presença de fenocristais de plagioclásio subeuédricos a euédricos nos anfibolitos, indicam que estes, pelo menos em parte, são diques deformados e paralelizados aos gnaisses.

A unidade contém intercalações de rochas ultramáficas 

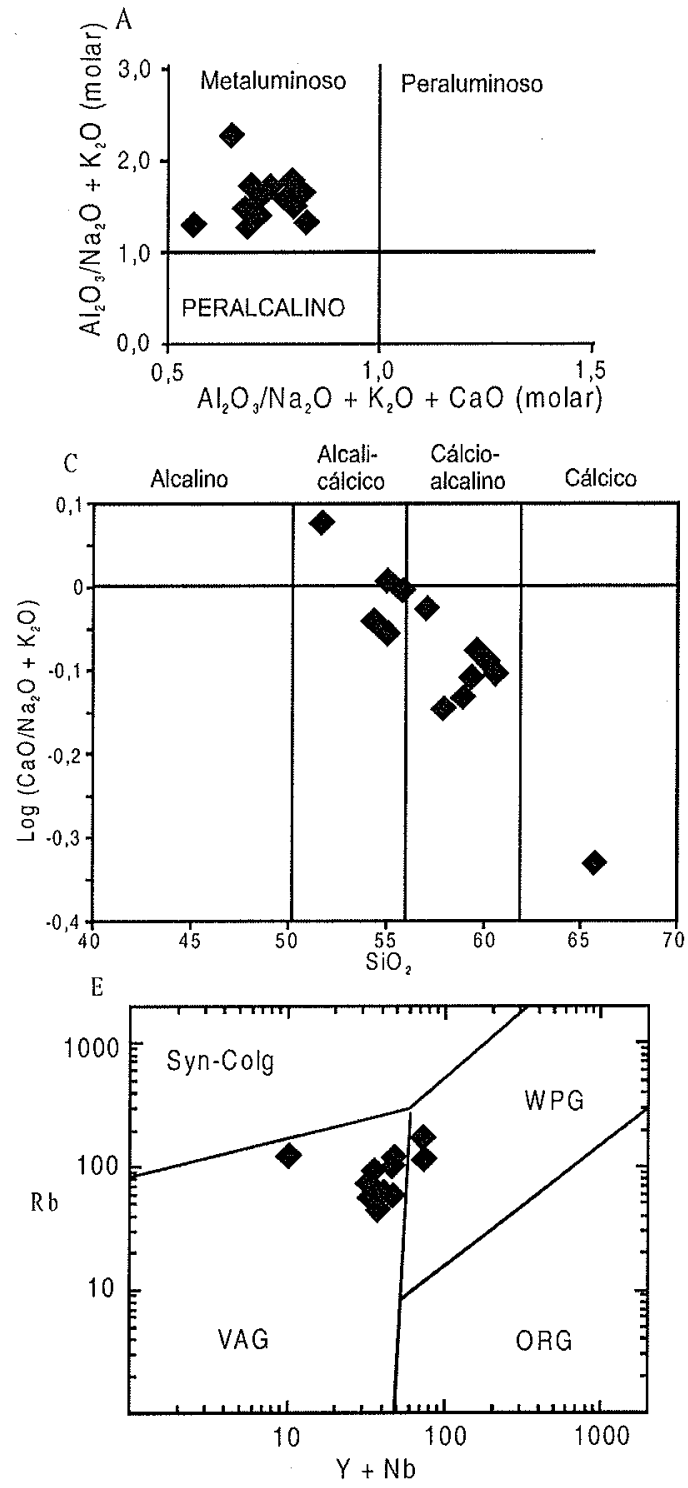
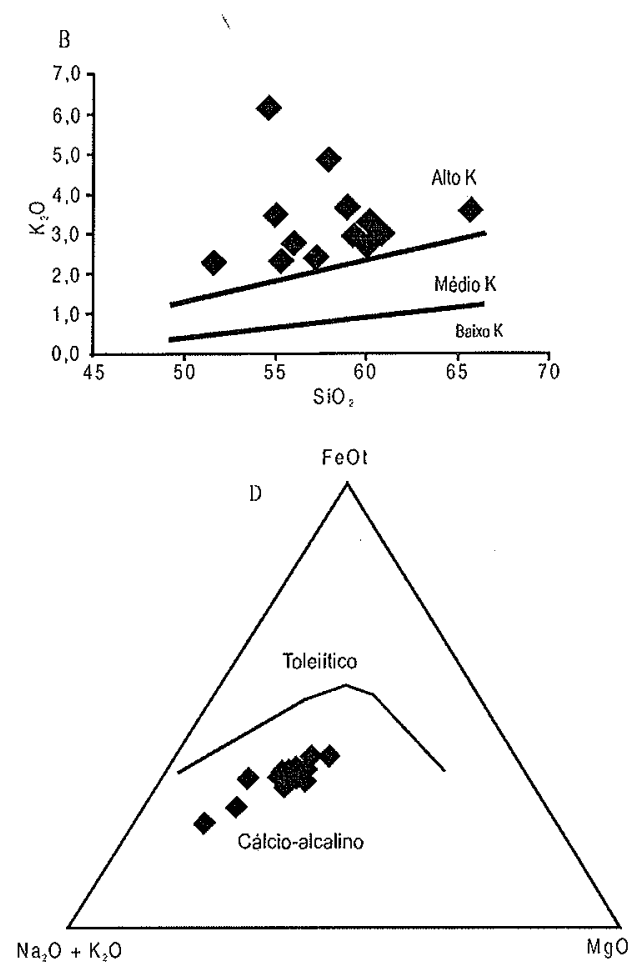

F

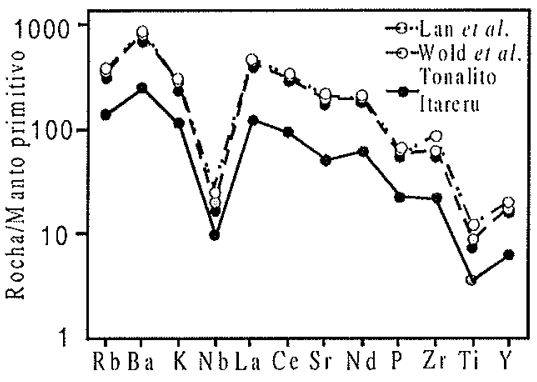

Figura 4-Diagramas geoquímicos para rochas do Tonalito Itareru. A: Índice de saturação de alumínio; $\mathrm{B:}: \mathrm{SiO}_{2} \times \mathrm{K}_{2} \mathrm{O} ; \mathrm{C}:$ índice de alcalinidade; D: diagrama AFM; E: diagrama de discriminação de ambiente tectônico (Pearce et al. 1984); F: diagrama de multielementos normalizados ao manto primitivo (Sun \& McDonough 1989), comparado com granitóides de zona de subducção (Lan et al. 1996, Wold et al. 1996).

(peridotitos serpentinizados), as quais podem hospedar mineralizações de cromita, como a observada na Mina de Pedra Preta, nas proximidades da cidade de Santa Luz (Araújo 1998).

A oeste, os gnaisses bandados estão em contato com rochas arqueanas representadas por gnaisses granodiofíticos cinza e migmatitos estromáticos. Esses gnaisses apresentam porções mais antigas (grey gneisses típicos) cortadas por diques máficos e, posteriormente, injetados por fundidos quartzo-feldspáticos róseos. ARQUITETURA GERAL EESTRUTURA INTERNA DO TI Como mencionado, as principais características estruturais do TI são a forte orientação linear de seus minerais e enclaves, e a quase ausência de foliação, caracterizando um típico tectonito L. Estrutura planar é observada apenas nas zonas de contato com as rochas encaixantes, ou onde o TI foi seccionado pelo Granodiorito Lagoa do Boi (Fig. 3).
A lineação mineral tem características magmáticas nas porções centrais, onde o corpo é pouco ou nada deformado. Apresenta direção variável de $\mathrm{N}$ a NW, com mergulho sempre em.baixo ângulo, alternadamente para norte e para sul (Fig. 6a). Essa lineação é marcada principalmente pela orientação de grãos euédricos de plagioclásio, biotita e anfibólio. Na porção centro-norte do TI, a lineação mineral tem atitude diferente. Nessa região ela é praticamente vertical e não se nota foliação marcante, apenas bandamento de fluxo magmático. Dessa região para norte, ou para sul, o ângulo de caimento da lineação mineral diminui até ficar sub-horizontal . Na porção centro-sul do TI, a ausência de foliação também é marcante. Nessa região, a lineação é de baixo ângulo com caimento de $0-20^{\circ}$ para $N-N W$ ou $S-S E$.

Os enclaves orientam-se sempre segundo a direção da lineação mineral. Nas porções menos deformadas formam, normalmente, 

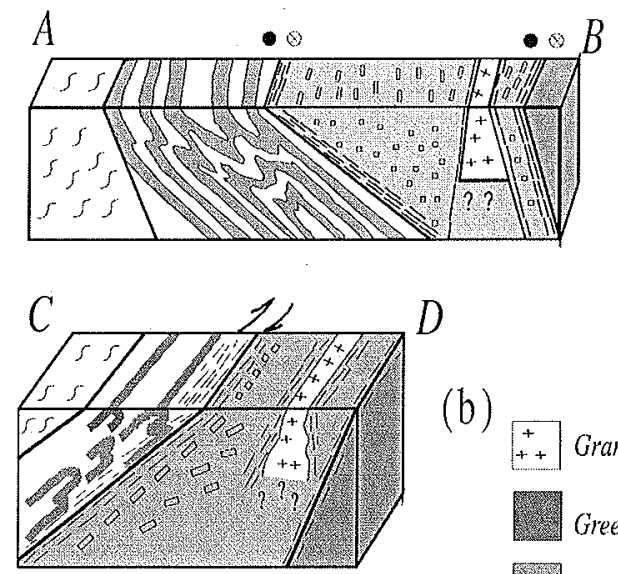

(b)

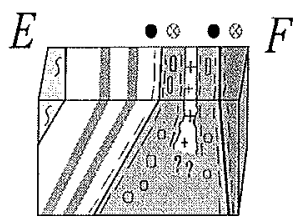

(c)
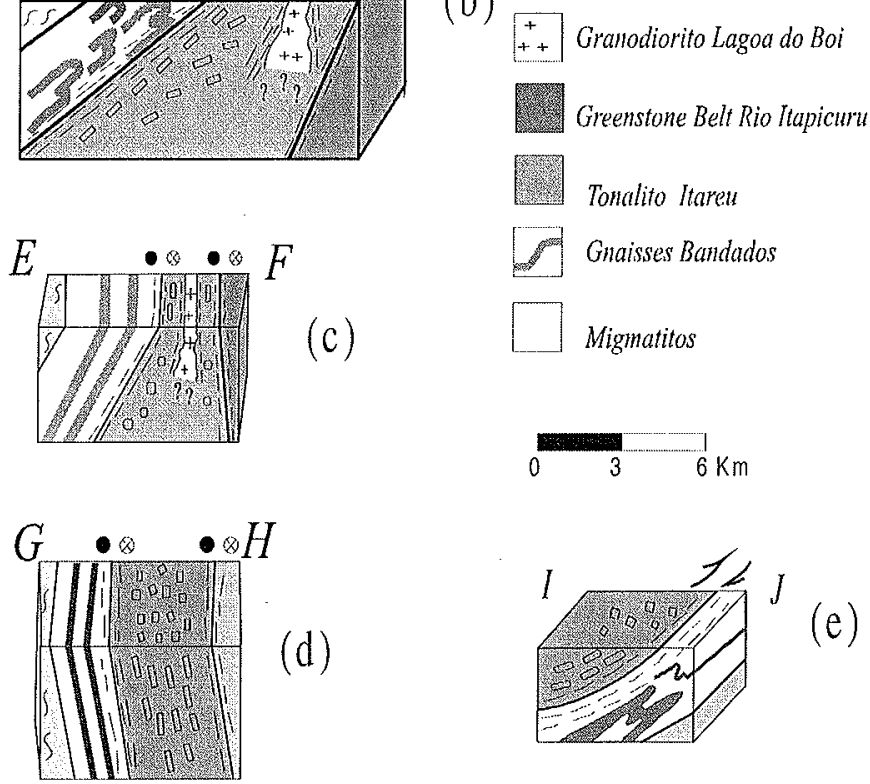

(d)
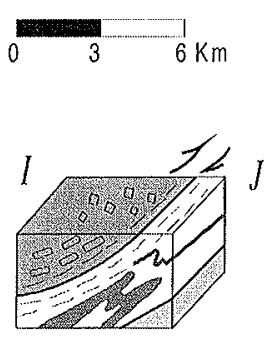

Figura 5 - Perfis geológicos esquemáticos ao longo do Tonalito Itareru e suas encaixantes. Vide figura 3 para localização. A seção I-J é geral não estando situada na figura 3

elipsóides prolatos, característicos de tectonitos do tipo L. Nas bordas, onde há desenvolvimento de foliação, normalmente têm formato oblato. Tais características e a ausência de enclaves dobrados ou "rompidos" indicam, provavelmente, que a orientação mineral é também a direção principal do fluxo magmático.

As bordas do TI são sempre deformadas, com estrutura planar bem desenvolvida e lineação de estiramento marcada por quartzo e plagioclásio estirados, segundo a direção preferencial N-NW a $\mathrm{N}-\mathrm{S}$. Nesses locais, o TI adquire estrutura gnáissica (augen gnaisse), com freqüiente desenvolvimento de foliação milonítica $S-C$, marcada por biotita.

De acordo com os critérios sugeridos por Paterson et al. (1989), o TI pode ser considerado uma intrusão sin-tectônica. De fato: (i) sua forma é extremamente alongada, com eixo longitudinal paralelo à principal direção de deformação regional; (ii) a orientação das lineações de minerais magmáticos, como anfibólio e plagioclásio, coincide com a orientação dos enclaves e da lineação de estiramento de quartzo e plagioclásio e, (iii) a passagem de estrutura magmática PFC (Pré Full Crystalization Fabric) para estrutura característica de deformação em estado sólido CPS (Crystal Plastic Strain Fabric), do centro para as bordas do corpo.

Ao longo de sua extensão, tanto o TI quanto as rochas encaixantes apresentam diferenças estruturais significativas.

Na porção sul, onde o corpo tem largura maior, os indicadores
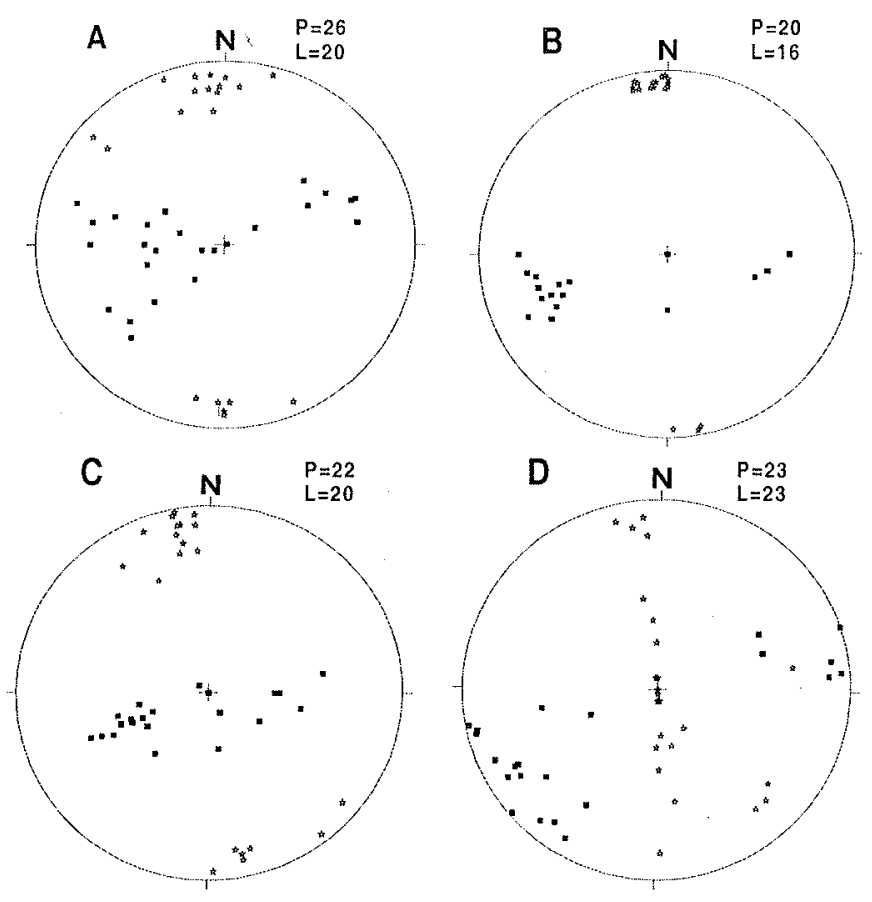

Figura 6 - Diagrama de polos de foliação $(P$, quadrado $) e$ lineação ( $L$, estrela) para o Tonalito Itareru. $A=$ região central; $B=$ leste; $C=$ oeste; $D=$ norte.

cinemáticos caracterizam movimentação relativa diferente na borda leste e oeste do TI.

$\mathrm{Na}$ borda leste, a foliação é bastante penetrativa, com direção preferencial N-NW e caimento entre $40^{\circ}$ e $60^{\circ}$ para E (Fig. 6 b), concordante com a foliação dos anfíbolitos encaixantes. A lineação de estiramento, representada por "filmes" de quartzo e plagioclásio estirados, é caracteristicamente direcional, com rumo N-NW e caimento máximo de $10^{\circ}$, alternadamente para $\mathrm{N}$ ou $\mathrm{S}$ (Fig. 6b). Os indicadores cinemáticos (sombras de pressão assimétrica em fenocristais de plagioclásio e foliação $S$-C) caracterizam movimentação sinistral com componente vertical reverso.

$\mathrm{Na}$ borda oeste, a foliação do TI tem direção semelhante à da borda $\mathrm{E}$, com caimento menor $\left(20^{\circ}-40^{\circ}\right)$, também para $\mathrm{E}$, e é concordante com a foliação dos gnaisses bandados (Fig. 6c). As lineações de estiramento são direcionais com orientação N-NW e mergulhos de $5^{\circ}$ a $10^{\circ}$ para $\mathrm{N}$ ou $\mathrm{S}$ (Fig. 6c). Os indicadores cinemáticos quase sempre caracterizam movimentação sinistral reversa, mas próximo ao contato SW do TI, os indicadores cinemáticos (sombras de pressão assimétricas) são dextrais reversos. Em função dessas diferenças cinemáticas, o extremo sul do TI foi caracterizado como uma rampa de cavalgamento de baixo ângulo. Como o transporte tectônico foi de NW para SE é esperado que na borda SE do TI os indicadores cinemáticos sejam sinistrais enquanto que na SW sejam dextrais, como observado.

Na porção sul do TI, os gnaisses bandados do Complexo Santa Luz apresentam uma característica estrutural marcante que não é observada nas rochas do TI. Eles exibem dobras fechadas, assimétricas, com plano axial inclinado, com baixo a médio ângulo de mergulho para $\mathrm{E}$, e eixos sub-horizontais a inclinados com direção aproximadamente N-S. Nos flancos dessas dobras são observadas lineações de estiramento mineral, com direção E-W mergulhando para $\mathrm{E}$, ausentes no $\mathrm{TI}$, indicando, juntamente com a 
assimetria das dobras, vergência para $\mathrm{W}$ anterior à intrusão do TI. Essas lineações de estiramento, característicamente down dip, são observadas também em outros locais, especialmente na região central do GBRI (Lacerda 2000). Elas ocorrem subordinadamente em domínios pouco afetados pelo evento deformacional regional principal ( $D_{2}$ ) de Alves da Silva (1994).

Ainda no extremo sul de exposição do TI (Fig. 3), os contatos com as encaixantes apresentam características estruturais diferentes. A foliação do TI inflete para aproximadamente E-W e é mais penetrativa. A lineação de estiramento, definida por quartzo e plagioclásio estirados, é bastante acentuada e caracteristicamente down dip, caindo com $20^{\circ}$ a $30^{\circ}$ para $\mathrm{N}-\mathrm{NW}$. Os indicadores cinemáticos (sombras de pressão assimétrica em fenocristais de plagioclásio e foliação $S$-C) indicam movimento reverso, caracterizando o fechamento sul do corpo como rampa de empurrão que colocou o TI sobre as rochas do Complexo Santa Luz (Fig. 3). Na região onde o corpo se estreita, na estrada entre Santa Luz e Itareru, ocorrem milonitos de gnaisses bandados do Complexo Santa Luz com foliação NE-SW, $30^{\circ}-50^{\circ} \mathrm{NW}$, e lineação de estiramento oblíqua, com caimento $20^{\circ}-40^{\circ} \mathrm{NW}$. Neste local, ocorre dobra assimétrica contemporânea à lineação de estiramento, indicando cavalgamento para SE. A atitude desta lineação coincide com a da lineação mineral magmática nesta porção do TI.

Na porção norte, onde o TI é mais estreito, as foliações das suas bordas são de alto ângulo. Os mergulhos variam de $70^{\circ}$ a subverticais, para Eou W, nos dois lados do TI (Fig. 6d). As encaixantes, a leste e a oeste, também mostram mergulhos fortes. As lineações de estiramento de ambas bordas são direcionais. No estereograma da Figura 6d, referente a toda a porção norte do corpo, nota-se passagem das lineações minerais subverticais, dominantes nas porções centrais do corpo, para as de estiramento direcionais das bordas. As lineações de estiramento E-W, observadas em alguns afloramentos de gnaisses bandados, na porção meridional, não são mais identificadas.

No TI ainda ocorrem bandas de cisalhamento discretas, com espessuras entre $10 \mathrm{~cm}$ e $30 \mathrm{~cm}$, e caracterizadas pela orientação dos fenocristais de plagioclásio e de grãos de anfibólio. A sua direção preferencial é N-S e, em geral, revelam cinemática sinistral.

Os diques aplíticos paralelos à foliação do TI, apresentam dobras locais, com eixo inclinado, coincidente com a direção de mergulho da foliação. Essas dobras são quase sempre sinistrais. Nas bordas do TI, onde o mesmo se acha mais deformado, os diques aplíticos apresentam ocasionalmente foliação incipiente, paralela à foliação do tonalito, e marcada por estiramento de quartzo.

O Granodiorito Lagoa do Boi caracteriza-se estruturalmente por estar sempre cortado por veios/diques aplíticos paralelos ou subparalelos à foliação principal. Diques máficos também são observados em menor proporção. Esses diques apresentam-se normalmente dobrados e com estruturas migmatíticas. As dobras mostram formas diferentes, desde abertas até fechadas, com plano axial aproximadamente $\mathrm{N}-\mathrm{S}$ e eixos entre $\mathrm{N} 340^{\circ}$ e $\mathrm{N} 020^{\circ}$, exibindo caimento médios $\left(30^{\circ}-50^{\circ}\right)$ para $N$. Os diques dobrados indicam movimentação sinistral e, em regiões mais deformadas, encontram-se bastante estirados, paralelos à direção principal da foliação magmática, apresentando lineações de estiramento de orientação principal $\mathrm{N} 340^{\circ} / 20^{\circ}$

GEOCRONOLOGIA U-PbE ISÓTOPOSDENd Umaamostra representativa do TI (SLM-16) foi datada com a sonda iônica SHRIMP II (Sensitive High-Resolution Ion Microprobe), na Curtin University, Australia. Cerca de 100 grãos de zircões da amostra foram colocados em uma montagem com resina epox, juntamente com zircões do padrão CZ3. A montagem foi fotografada, para facilitar a localização dos grãos a serem analisados, e alguns grãos foram estudados por microscopia eletrônica de varredura para verificação da estrutura interna dos zircões. Este estudo revelou que os zircões do Tonalito Itareru exibem zoneamento oscilatório e em setores, típico de rochas ígneas (e.g. Rubatto \& Gebauer 2000), e contém inclusões aciculares de zircões menores e apatita. Domínios limpos dos zircões foram analisados na SHRIMP II. Os procedimentos de operação foram aqueles descritos por Compston et al. (1984) e as condições de operação foram aquelas descritas em Nelson (1997). Vinte análises do padrão CZ3 indicaram um erro $\mathrm{U} / \mathrm{Pb}$ de calibração de $2,30 \%$. As correções de chumbo comum foram feitas assumindo composições de chumbo comum de Broken Hill para todas as análises dos zircões.

Para o cálculo da idade, foram considerados apenas zircões entre $95 \%$ e $105 \%$ de discordância em relação à concórdia. O grau de discordância reflete perda ou ganho de $\mathrm{Pb}$ (ou U). Com isso, as análises discordantes foram consideradas idades mínimas.

De um total de 25 análises, 16 forneceram uma idade ${ }^{207} \mathrm{~Pb} / 206 \mathrm{~Pb}$ de $2109 \pm 5 \mathrm{Ma}$ (Fig. 7). Por suas características tipicamente magmáticas, a idade obtida é interpretada como de intrusão sintectônica do Tonalito Itareru.

Dados de isótopos de Nd foram obtidos em amostras do TI e do Granodiorito Lagoa do Boi. As análises foram realizadas no Laboratório de Geocronologia da Universidade de Brasilia, segundo os procedimentos apresentados em Gioia \& Pimentel (2000).

As idades-modelo $\mathrm{T}_{\mathrm{DM}}$ para o TI situam-se entre 2,33 Ga e 2,40 Ga. Para a idade de cristalização $(2109 \mathrm{Ma})$, os valores de $\stackrel{a}{\text { Nd(t) }}$ situam-se entre 0 e $-0,79$, sugerindo que o TI tem origem associada a um protólito com pouca residência crustal e originado de fonte magmática predominantemente juvenil.

As idades-modelo Nd do Granodiorito Lagoa do Boi (2,41-2,42 $\mathrm{Ga})$, são semelhantes às encontradas no TI, suportando a possibilidade deste ter sido fonte para o magma progenitor daquele.

DISCUSSÃO E CONCLUSÕES O Tonalito Itareru é um corpo alongado, de composição tonalito-diorítica a granodiorítica, rico

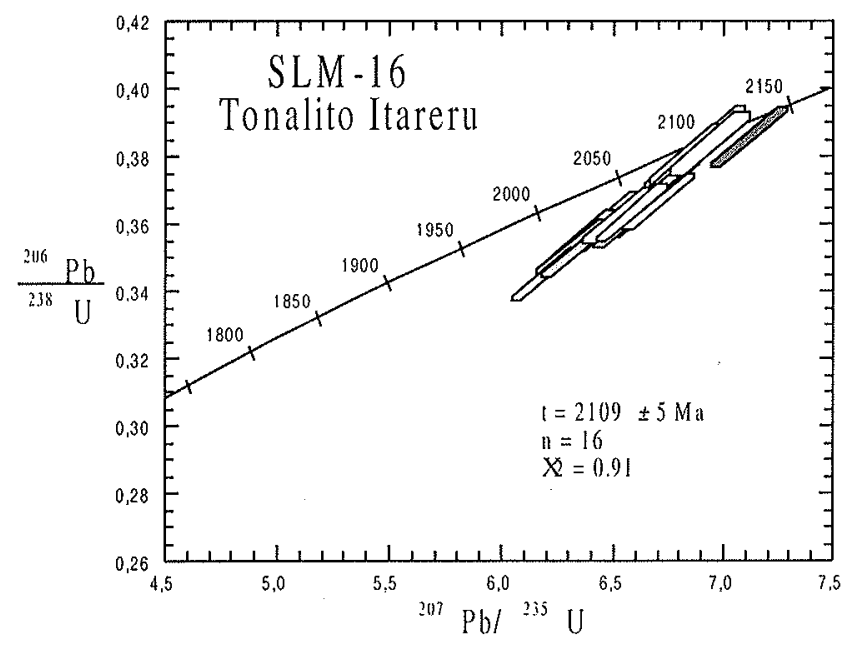

Figura 7 - Diagrama concordia para a amostra SLM-16 do Tonalito Itareru. Análises obtidas na SHRIMP II. Cinza escuro = análises $>2 \mathrm{~s}$ da média; cinza claro $=$ análises $>5 \%$ de discordância. 
em enclaves dioríticos, e colocado sin-tectonicamente ao longo do limite ocidental do terreno granito-greenstone do Rio Itapicuru com o embasamento arqueano. A geoquímica de suas rochas mostrou que se trata de um corpo cálcio-alcalino de alto potássio, metaluminoso e com assinatura geoquímica semelhante à de rochas plutônicas de arco insular, embora não necessariamente este seja o seu contexto tectônico. Estudos isotópicos revelaram uma idade de cristalização ${ }^{207} \mathrm{~Pb} /{ }^{206} \mathrm{~Pb}$ (SHRIMP) de $2109 \pm 5 \mathrm{Ma}$ e idades-modelo $\mathrm{T}_{\mathrm{DM}}$ de cerca de $2,33-2,40 \mathrm{Ga}$, com $\mathrm{e}_{\mathrm{Nd}(1)}$ entre $0 \mathrm{e}-$ 0,79 que são compatíveis com ambiente tectônico de arco.

No GBRI, ainda são escassos os trabalhos regionais que definam com clareza o seu ambiente geotectônico e conseqüentemente o de geração do TI. Nada se sabe sobre a existência de uma margem acrescionária e há discordância entre os modelos de ambientes propostos na literatura, os quais ora envolvem a colisão entre placas oceânicas, com incertezas quanto ao sentido da subducção, isto é, para leste (Padilha \& Melo 1991, Silva 1992) ou para oeste (Figueiredo 1989, Teixeira \& Figueiredo 1991), ora envolvem modelos alternativos de rifte (Matos \& Conceição 1993, Alves da Silva 1994).

A caracterização da natureza sin-tectônica de um corpo magmático é de grande importância no entendimento da evolução de uma área, principalmente no que tange à possibilidade de datar os eventos tectônicos. O TI é um corpo sin-tectônico segundo as seguintes características: (i) forma extremamente alongada, com eixo longitudinal paralelo à principal direção de deformação regional; (ii) orientação das lineações de minerais magmáticos, como anfibólio e plagioclásio, que coincide com a orientação dos enclaves e com a lineação de estiramento de quartzo e plagioclásio e, (iii) passagem de estrutura magmática PFC (Pré Full Crystalization Fabric) para estrutura característica de deformação em estado sólido CPS (Crystal Plastic Strain Fabric) do centro para as bordas do corpo.

Considerando a lineação mineral vertical, observada nas porções centrais do corpo, onde ele é menos deformado, passando gradativamente a subhorizontal e horizontal para sul e para norte, pode-se sugerir que o magma progenitor do TI teve pelo menos um foco de propagação na região centro-norte onde a lineação é vertical e os enclaves são abundantes, marcando fluxos direcionados em vários sentidos (Fig. 8). A partir deste conduto, teve fluxo controlado pela tectônica regional. Outra possibilidade é a de ter havido uma combinação de espraiamento de fluxo, com migração magmática em forma de pluma, com a ação tectônica transpressiva regional.

As características estruturais do TI também permitem tecer considerações sobre o regime tectônico vigente durante a sua colocação. O formato oblato dos enclaves nas partes marginais do corpo indica ação importante de um componente de achatamento, característica observada, por exemplo, também nos enclaves do cinturão tonalítico de North Victoria Land (Musumeci 1999). Em seguida, passou a dominar o regime de cisalhamento, melhor desenvolvido na região meridional do TI, onde indicadores cinemáticos dextrais, a SW e, sinistrais a SE, caracterizam uma rampa de empurrão de baixo ângulo com topo para SE.

Em conjunto, a presença no TI de lineações de estiramento mineral que variam de down dip, passando a oblíqua e direcional, além da ação de achatamento e cisalhamento são evidências estruturais de tectônica transpressiva que atuou durante o seu alojamento, de modo similar ao descrito por Paterson et al. (1989). As oscilações de caimento das lineações, ora em baixo ângulo para $\mathrm{N}$ NW, ora para S-SE, podem estar associadas ao encurtamento regional causado pela compressão NW-SE (Alves da Silva 1994).

O mecanismo de colocação mais adequado aos dados estruturais observados é o de injeção e expansão lateral, conforme descrito por Ingran \& Hutton (1994). Nesse caso, o magma sob pressão aproveita-se das descontinuidades mecânicas causadas pelos grandes alinhamentos intracrustais para se alojar, sendo depois "dirigido" pela tectônica direcional. Durante o cisalhamento puro ocorre compressão horizontal com extensão vertical associada. Essa fase poderia ser a responsável pela subida do magma que migraria paralelamente à orientação regional imposta pela tectônica oblíqua subseqüente.

A comparação entre as estruturas apresentadas pelo TI e as estruturas regionais sustentam as seguintes conclusões: (i) as direções $\mathrm{N}$ a NW das foliações das rochas do TI concordam com a foliação regional principal, desenvolvida durante o evento $D_{2}$

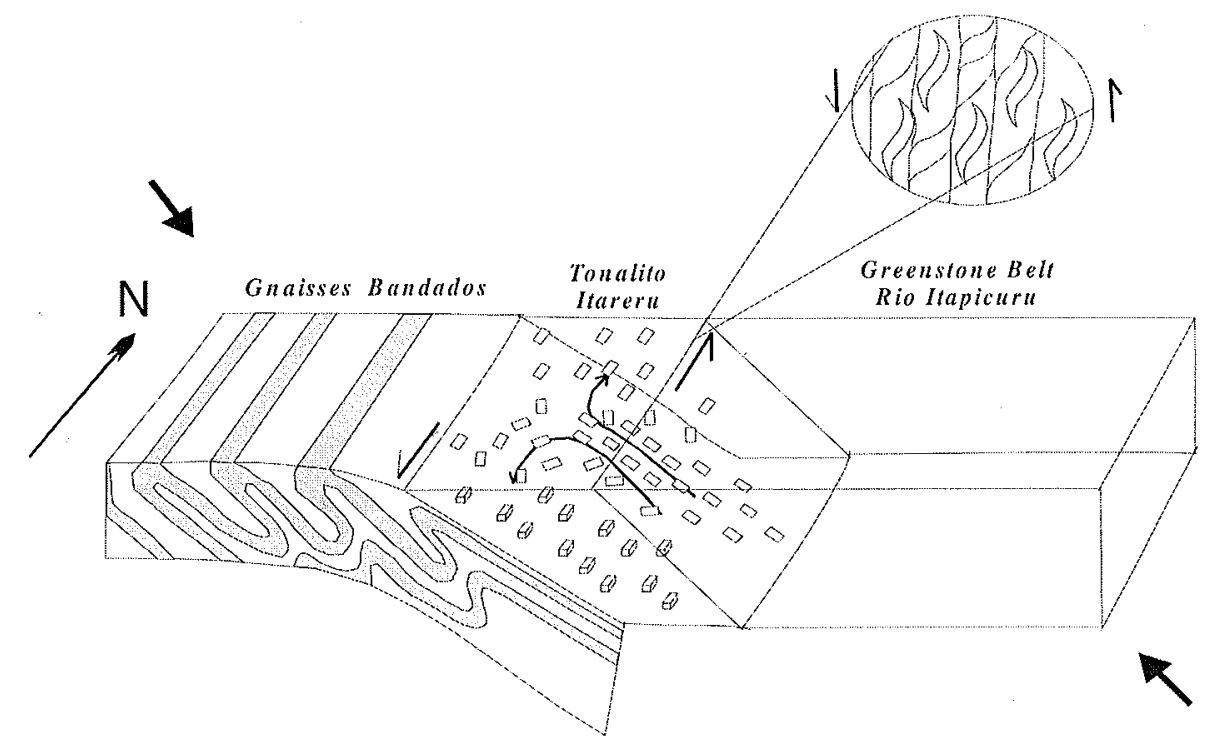

Figura 8 - Esboço da colocação do Tonalito Itareru em relação à tectônica regional. Comportamento da lineação mineral de acordo com observações de campo. 
transcorrente (Alves da Silva 1994); (ii) as lineações minerais e de estiramento são paralelas à essa direção, assim como os enclaves; (iii) os indicadores cinemáticos em geral também coincidem com a movimentação relativa sinistral das zonas de cisalhamento desenvolvidas durante o evento supracitado e, (iv) o TI apresenta, em pelo menos duas localidades, rampas de empurrão, com topo deslocado para S-SE. O posicionamento dessas rampas, em relação aos anteparos e à deformação regional, sugere que foram geradas durante o evento $\mathrm{D}_{2}$ em regime tipicamente transpressivo.

Essas características sustentam a hipótese de que sua colocação se iniciou na primeira fase $\left(\mathrm{F}_{1}\right)$ do evento $\mathrm{D}_{1}$ regional, relacionado ao início do fechamento da Bacia Itapicuru, já que apresenta rampas de cavalgamento características dessa fase e lineação magmática paralela à lineação de estiramento nos gnaisses bandados regionais. $\mathrm{O}$ TI foi deformado durante a fase $\mathrm{D}_{2}$, sobretudo em suas bordas, como demonstrado pela foliação de alto ângulo N-NW, paralela à foliação regional mais forte da fase $\mathrm{D}_{2}, \mathrm{e}$ pela lineação de estiramento direcional. A deformação afetou o TI ainda em estado plástico (atestado pela lineação magmática associada ao evento $\mathrm{D}_{2}$ ) até seu resfriamento (presença das texturas de deformação em estado sólido).

Essas informações demonstram que a classificação para os granitóides do Núcleo Serrinha (Rios et al. 1998), em parte fundamentada em critérios deformacionais, deve ser revista. Com os trabalhos de datação de alguns corpos granitóides, que vem sendo realizados na região (por exemplo, Mello et al. 1999, Mello 2000), essa deficiência vem aparecendo. Prova disto é o corpo granítico de Trilhado, localizado $6 \mathrm{~km}$ a SE de Nordestina. Este corpo é intrusivo em metabasaltos do GBRI e praticamente não está deformado, o que pelos critérios de Rios et al. (1998) deveria pertencer ao grupo G3. Entretanto, a idade U-Pb SHIRMP de 2150 Ma obtida por Mello (2000) o posiciona como o granitóide mais antigo do GBRI. Esse fato mostra que a deformação não atingiu de forma homogênea as rochas do GBRI, que tem algumas porções, ainda não bem delimitadas, preservadas da deformação regional mais intensa. Para que uma classificação mais precisa seja proposta é preciso que se conheçam as idades dos corpos.

As rochas encaixantes do TI também trazem importantes informações sobre o papel que o mesmo desempenhou na evolução regional. O grau metamórfico mais elevado e a idade arqueana do Complexo Santa Luz (Oliveira et al. 2002a), além do padrão da deformação, diferem bastante das rochas do GBRI. Os gnaisses bandados do Complexo Santa Luz exibem intensa deformação dúctil caracterizada por foliação milonítica e dobras apertadas, provavelmente formadas a partir dos cavalgamentos mensionados anteriormente e foram metamorfisados nas condições da fácies anfibolito. Já as rochas supracrustais do GBRI têm idade paleoproterozóica (Silva 1992), exibem um padrão de deformação diferente, caracterizada por uma sucessão de sinformes e antiformes de grande amplitude e foliação desenvolvida por zonas de cisalhamento N-S, e foram metamorfisadas na facies xisto verde, em condições crustais mais rasas. Essas diferenças entre as rochas encaixantes do TI sustentam a possibilidade de que ele possa marcar uma descontinuidade de terrenos.

Por outro lado, o posicionamento geotectônico do TI e suas características geoquímicas de suites intermediárias a ácidas poderiam levantar a possibilidade dele representar o conduto das rochas vulcânicas intermediárias do GBRI. Essa hipótese é descartada nos diagramas da figura 9, onde foram plotadas dados químicos do TI e de metandesitos do GBRI (Silva 1987). No gráfico $\mathrm{Rb} \times \mathrm{K}_{2} \mathrm{O}$, as rochas do TI são mais ricas em $\mathrm{K}$ que as metavulcânicas intermediárias do GBRI. No gráfico $\mathrm{K}_{2} \mathrm{O} \times \mathrm{MgO}$ também se nota que o TI é mais rico em $\mathrm{Mg}$ que os metandesitos do GBRI. Essas características, i.e., teores mais elevados de $\mathrm{MgO}, \mathrm{K}_{2} \mathrm{O}$ e Rb no TI do que nos metandesitos, indicam evoluções petrogenéticas distintas, sendo incompatíveis com a hipótese do primeiro ser conduto dos últimos.

As características de campo e os dados isotópicos posicionam a geração do TI entre a dos granitóides juvenís (Barrocas e Teofilândia, conforme Barrueto et al. 1998) e a anatexia do embasamento. Nas intrusões de Barrocas e Teofilândia não são conhecidos xenólitos (Barrueto 2002). Portanto, no campo, não há evidências de interação desses corpos com algum tipo de crosta preexistente. No TI, por outro lado, observa-se xenólito de rocha metabasáltica, indicando interação com crosta mais antiga. $\mathrm{O}$ granitóide de Ambrósio, por sua vez, tem forte componente crustal em sua gênese e é considerado por Lacerda (2000) como anatético.

Em suma, o TI é considerado um marcador do regime transpressivo que atingiu a região no Paloeproterozóico, tendo o seu alojamento ocorrido entre as duas principais fases de deformação regional, ou no início da segunda. O caráter sin-tectônico do TI e a idade de $2109 \mathrm{Ma}$, posicionada entre a intrusão dos granitóides juvenis de Barrocas e Teofilândia (2127-2130 Ma, $c f$. Chauvet et al. 1997 e Mello 2000) e a anatexia do embasamento
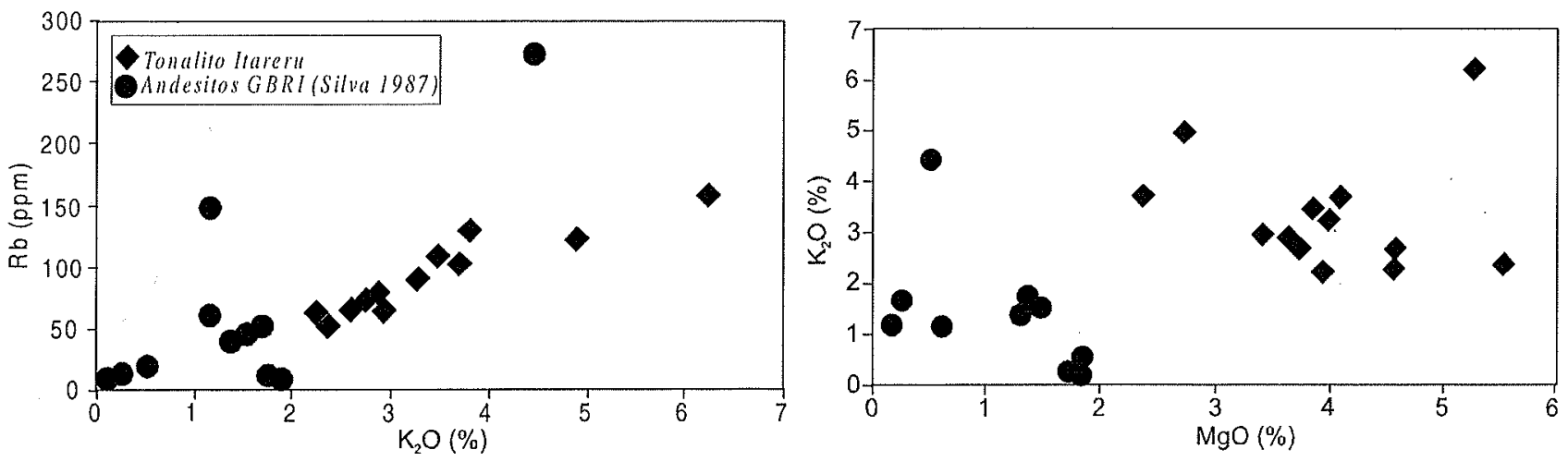

Figura 9 - Diagramas $\mathrm{K}_{2} \mathrm{O} \times \mathrm{Rb}$ e $\mathrm{MgO} \times \mathrm{K}_{2} \mathrm{O}$ comparando rochas do Tonalito Itareru com andesitos do Greenstone Belt do Rio Itapicuru (Silva 1987) 
arqueano há cerca de $2080 \mathrm{Ma}$ (Domo de Ambrósio, $c f$. Mello et al. 1999) constituem forte evidência a favor de que a intrusão do TI possa representar a época da colisão continente-continente no segmento norte do Orógeno Itabuna-Salvador-Curaçá.

Agradecimentos Aos Profs. Asit Choudhuri (Unicamp), Cristina Wiedeman-Leonardos (UnB), Brian Windley (University of Leicester) e Luiz César Corrêa-Gomes (GEMA-IGUFBA/CEFET-
BA) pelas contribuições em diversas etapas desta pesquisa. Ao CNPq, pelas bolsas de mestrado para MJC e de produtividade para EPO (Proc. 300.845/91-0). O apoio financeiro da FAPESP (Proc. 99/05760-4) viabilizou os trabalhos de campo e a aquisição dos dados isotópicos no Laboratório de Geocronologia da Universidade de Brasilia e na SHRIMP da University of Western Australia. Ao Prof. Fernando Alkimim e aos revisores da RBG pelas sugestões ao manuscrito.

\section{Referências}

Alves da Silva F.C. 1994. Etude structurale du Greenstone Belt Paleoproterozoique du Rio Itapicuru (Bahia, Brésil). Orleans, Géosciences, Université d'Orleans, Tese de Doutoramento, 340p.

Araújo M.G.S. 1998. Caracterização Metalogenética do Depósito Cromitífero de Pedras Pretas, Santa Luz-Ba. Instituto de Geociências, Universidade Estadual de Campinas, Campinas, Dissertação de Mestrado, 138p.

Barbosa J.S.F. 1986. Constitution Lithologique et Metamorphic de la Region granulitique du Sud de Bahia, Brésil. Université Pierre et Marie Curie (Paris), Mémoir Sciences de La Terre, 86-34, 401p.

Barrueto H.R. 2002. Petrogênese das intrusões compostas de Teofilândia e Barrocas, Greenstone Belt do Rio Itapicuru, Bahia, Brasil. Instituto de Geociências, Universidade Estadual de Campinas, Campinas, Tese de Doutoramento, $188 \mathrm{p}$.

Barrueto H.R., Oliveira E.P., Dall' Agnol R. 1998. Trace element and Nd isotope evidence for juvenile, arc-related granitoids in the southern portion of the Paleoproterozoic Rio Itapicuru Greenstone Belt (RIGB), Bahia, Brazil. In: SBG, Congr. Bras. Geol., 40, B. Horizonte, Anais, 520.

Batista J.J., Nesbitt R.W., Pires P.F.R 1998. Presença do embasamento arqueano no greenstone belt do Rio Itapicuru (Bahia) - resultados geocronológicos por ICP-MS/LA. In: SBG, Congresso Brasileiro de Geologia, 40, Belo Horizonte, Anais, 67.

Brito Neves B.B., Cordani U.G., Torquato J.R.F. 1980. Evolução geocronológica do Estado da Bahia. In: Inda, H. A. V; Duarte, F. B. (eds.), Geologia e Recursos Minerais do Estado da Bahia, Textos básicos: Secretária de Minas e Energia, Salvador-Brasil, 3: 1-10.

Brown G.C. 1982. Calc-alkaline intrusive rocks: their diversity, evolution and relation to volcanic arcs. In: R.S. Thorpe (ed.) Andesites. Wiley, London, 437-461.

Carvalho M.J. 2001. Geologia e Geoquímica do Tonalito-diorito Itareru, Margem Oeste do Greenstone Belt do Rio Itapicuru, Bahia-Brasil. Instituto de Geociências, Universidade Estadual de Campinas, Campinas, Dissertação de Mestrado, 71p.

Chauvet A., Guerrot C., Alves da Silva F.C., Faure M. 1997. Géochronologie ${ }^{207} \mathrm{~Pb} /{ }^{206} \mathrm{~Pb}$ et ${ }^{40} \mathrm{Ar} /{ }^{39} \mathrm{Ar}$ des granites paléoprotérozoiques de la ceinture de roches vertes du Rio Iapicuru (Bahia, Brésil). Comptes Rendus de l'Academie des Sciences, Serie II a, 324:293-300.

Condie K. 1997. Plate tectonics and crustal evolution. 4 ed. Butterworth Heinemann. $282 \mathrm{p}$.

Compston W., Willians I.S., Meyer C. 1984. U-Pb geochronology of zircons from lunar breccia 73217 using a sensitive hight mass-resolution ion microprobe. Jour: Geophys.Resear, 89:B252-534.

Davison I., Teixeira J.B.G, Silva M.G., Rocha Neto M.B., Matos F.M.V, 1988. The Rio Itapicuru Greenstone Belt, Bahia, Brazil: Struture and stratigraphical outline. Precambrian Res., 42:1-17.

Figueiredo M.C.H. 1989. Geochemical evolution of eastern Bahia, Brazil:
A probable Early Proterozoic subduction related magmatic arc. $J$. South Amer. Earth Sci. 2:131-145.

Gioia S.M.C.L., Pimentel M.M. 2000. The Sm-Nd isotopic method in the geochronology laboratory of the University of Brasilia. An. Acad. Bras. Ci, 72:219-245.

Inda H.A.V., Barbosa J.F. 1978. Mapa geológico do Estado da Bahia. (Escala 1:1.000.000). Secretaria de Minas e Energia da Bahia.

Ingram G.M., Hutton D.H.W. 1994. The Great Tonalite Sill: Emplacement into a contractional shear zone and implications for Late Cretaceous to early Eocene tectonics in southeastern Alaska and British Columbia. Geol. Soc. Amer. Bull., 106: 715-728.

Kishida A. 1979. Característica Geológica e Geoquímica da sequência vulcano-sedimentar do Médio Rio do Itapicuru Bahia. Salvador. Instituto de Geociências, Universidade Federal da Bahia, Salvador, Dissertação de Mestrado, 98p.

Kishida A., Riccio L. 1980.Chemostratigraphy of lava sequences from the Rio Itapicuru Greenstone Belt, Bahia, Brazil. Precambrian Res. 11:161-178.

Kosin M., Guimarães J.T., Abram M.B. (orgs.) 1999. Folha Aracaju-SW, folha SC.24-Y. Salvador, CPRM. Programa Levantamentos Geológicos Básicos do Brasil - PLGB. No prelo.

Lacerda C.M.M. 2000. Evolução estrutural e petrogenética do Domo Granodiorítico de Ambrósio: Implicações para o mecanismo de colocação. Campinas. Instituto de Geociências, Universidade Estadual de Campinas, Campinas, Tese de Doutoramento, $120 \mathrm{p}$.

Lan C.Y., Jahn B.M., Mertzman S.A., Wu T.W. 1996. Subductionrelated granitic rocks of Taiwan. J. Southeast Asian Earth Sci., 14: $11-28$.

Mascarenhas J.F. 1979. Evolução geotectônica do Precambriano do estado da Bahia. In: H.A.V. Inda (coord.) Geologia e recursos minerais do estado da Bahia, SME/COM, Bahia, Textos Básicos, 2: 55165.

Mascarenhas J.F., Garcia T.W. 1989. Mapa geocronológico do Estado da Bahia. Superintendência de Geologia e Recursos Minerais, Secretaria das Minas e Energia, Bahia. Texto Explicativo, 189 p.

Matos F.M.V, Conceição H. 1993. Granitogênese associada à parte oeste do Cráton Serrinha e o Greenstone Belt do Rio Itapicuru: geologia e tipologia. In: SBG, Simpósio do Cráton do São Francisco, 2, Salvador, Anais, 60-62.

Matos F.M.V. 1988. Um estudo estrutural e petrografico no domo granito gnáissico de Ambrósio no Greenstone Belt do Rio Itapicuru. Bahia. Brasil. Instituto de Geociências, Universidade Federal da Bahia, Salvador, Dissertação de Mestrado, 85p.

Mello E.F. 2000. Estudos isotópicos do Greenstone Belt do Rio Itapicuru, Bahia: Evolução crustal e metalogenia do ouro. Instituto de Geociências, Universidade Estadual de Campinas, Campinas, Tese de Doutoramento, 162p. 
Mello E.F., Lacerda C.M.M., Oliveira E.P., McNaughton N.J. 1999. SHRIMP U-Pb geochronology on xenotime and zircon from the Ambrosio dome, Rio Itapicuru greenstone belt, Brazil: A major syntectonic granodiorite intrusion. In: II South American Symposium on Isotope Geology, Cordoba-Argentina, Proceedings, 331-334.

Melo R.C. 1991. Programa de Levantamentos Geológicos Básicos do Brasil (PLGB). Folha Pintadas-SC.24-Y-D-V, 1;100.000, Estado da Bahia. Brasília, DNPM/CPRM, 192p.

Musumeci G. 1999. Magmatic belts in accretionary magins, a key for tectonic evolution: the Tonalite Belt of North Vuctoria Land (East Antarctica). Jour: Geol. Soc., London, 156:177-189.

Nelson D.R. 1997. Compilation of SHRIMP U-Pb zircon gechronology data, 1996. Geol. Surv. Western Austr, Rec. 1997/2: 189 p.

Oliveira E.P., Tarney J. 1995. Genesis of the copper-rich Caraiba norite-hypersthenite complex, Brazil. Mineral. Dep., 30:351373.

Oliveira E.P., Mello E.F., McNaughton N. 2002a. Reconnaissance $\mathrm{U}-\mathrm{Pb}$ geochronology of early Precambrian quartzites from the Caldeirão belt and their basement, NE São Francisco Craton, Bahia, Brazil: Implications for the early evolution of the Palaeoproterozoic Salvador-Curaçá Orogen. Jour: South Amer: Earth Sci., 15:349-362.

Oliveira E.P., Mello E.F., McNaughton N.J., Choudhuri A. 2002 b. SHRIMP U-Pb age of the basement to the Rio Itapicuru Greenstone Belt, NE São Francisco craton. In: SBG, Congresso Brasileiro de Geologia, 41, João Pessoa, Anais, 522.

Padilha A.V.1992. Estruturas e Tectônica. In: A.R. Sampaio (ed.). Programa de Levantamentos Geológicos Básicos do Brasil (PLGB). Folha Gavião-SC.24-Y-D-II; 100.000, Estado da Bahia. Brasília, DNPM/CPRM, 51-57.

Padilha A.V., Melo R.C. 1991. Evolução Geológica. In: H.S.C Loureiro (ed.) Programa de Levantamentos Geológicos Básicos do Brasil (PLGB). Folha Mundo Novo-SC.24-Y-D-IV, 100.000, Estado da Bahia. Brasília, DNPM/CPRM, 133-157.

Parry M., Stípská P., Schulmann K., Hrouda F., Jesek J., Kröner A. 1997. Tonalite Sill emplacement at an oblique plate boundary: northeastern margin of the Bohemian Massif. Tectonophysics, 280: 61-81.

Paterson S.R., Vernon R.H., Tobisch O.T. 1989. A review of criteria for the identification of magmatic and tectonic foliations in granitoids. J. Struct. Geol, 11(3): 349-363.

Pearce J.A., Harris N.B. W., Tindle A.G. 1984. Trace element discrimination diagrams for the tectonic interpretation of granitic rocks. J. Petrol., 25:956-983.

Rios C.R., Conceição H., Macambira J.B. M., Burgos C.M.G., Peixoto A.A., Cruz Filho B.E., Oliveira L.L., Lisboa M.P. 1998. Granitogênese da parte meridional-oriental do Núcleo Serrinha: idade, petrografia e geoquímica. In: H. Conceição, M.J.M. Cruz,
J.H.S. Sá, P. Sabaté (eds.) Contribuição ao estudo dos granitos e rochas correlatas. Publicação especial da Sociedade Brasileira de Geologia, Núcleo Bahia-Sergipe, 5: 91-113.

Rios C.R., Davis D.W., Conceição H., Macambira J.B.M., Peixoto A.A., Cruz Filho B.E., Oliveira L.L. 2000. Ages of granites of the Serrinha Nucleus, Bahia (Brazil): an overview. Rev. Bras. Geoc., 30:74-77.

Rubatto D., Gebauer D. 2000. Use of cathodoluminescence for U-Pb zircon dating by ion microprobe: some examples from the Western Alps. In: M. Pagel, V. Barbin, P. Blanc, D. Ohnenstetter (eds.), Cathodoluminescence in Geosciences. Springer Verlag, 373-400.

Schimid S.M., Aebli H.R., Heller F., Zingg A. 1989. The role of the Periadriatic Line in the tectonic evolution of the Alps. In: M.P. Coward, D. Dietrich, R.G. Park (eds.), Alpine Tectonics. Geo.l Soc. London Spec. Public., 45, 153-171.

Silva M.G. 1983. A Sequência Vulcano sedimentar do Médio Rio Itapicuru, Bahia: Caracterização Petrográfica, Considerações petrogenéticas Preliminares e Zoneamento Metamórfico. Salvador. Instituto de Geociências, Universidade Federal da Bahia, Salvador, Dissertação de Mestrado, 88p.

Silva M.G. 1987. Geochemie, Petrologie und tektonische Entwicklung eines proterozoischen Grunsteingurtels: Rio Itapicuru, Bahia, Brasilien. Universitat Freiburg, Deutschland, Tese de Doutoramento, $180 \mathrm{p}$.

Silva M.G. 1992. O Greenstone Belt do Rio Itapicuru: uma bacia do tipo back arc fóssil. Rev. Bras. Geoc., 22:157-166.

Silva M.G. 1997. Geoquímica, geocronologia e isótopos (Sm-Nde $\mathrm{Pb}-\mathrm{Pb}$ ) da Sequência Vulcano-Sedimentar do Rio Itapicuru (Bahia, Brasil) revelando uma parte da história da evolução crustal, proterozóica inferior, do Cráton do São Francisco. In: X Semana de Geoquímica / IV Congresso de Geoquímica dos Paises de Língua Portuguesa, Braga, Portugal, Actas, 409-412.

Sun S.S., McDonough W.F. 1989. Chemical and isotopic systematics of oceanic basalts: implications for mantle composition and pocesses. In: A.D. Saunders \& M.J. Norry (eds.) Magmatism in the Ocean Basins. Geol. Soc. Spec. Public., 42:313-345.

Teixeira W., Figueiredo M.C.H. 1991. An outline of Early Proterozoic crustal evolution in the São Francisco Craton, Brasil: a review. Precamb. Res. 53:1-22

Wold B., Gore-Gambella Geotraverse Team 1996. Tonalitetrondhjemite-granite genesis by partial melting of newly underplated basaltic crust: an example from the Neoproterozoic Birbir magmatic arc, western Ethiopia. Precamb. Res., 76:3-14.

Manuscrito TM-007

Recebido em 08 de novembro de 2002

Revisão dos autores em 12 de dezembro de 2002 Revisão aceita em 15 de dezembro de 2002 